\title{
From Projectile Points to Microprocessors- The Influence of Some Industrial Minerals
}

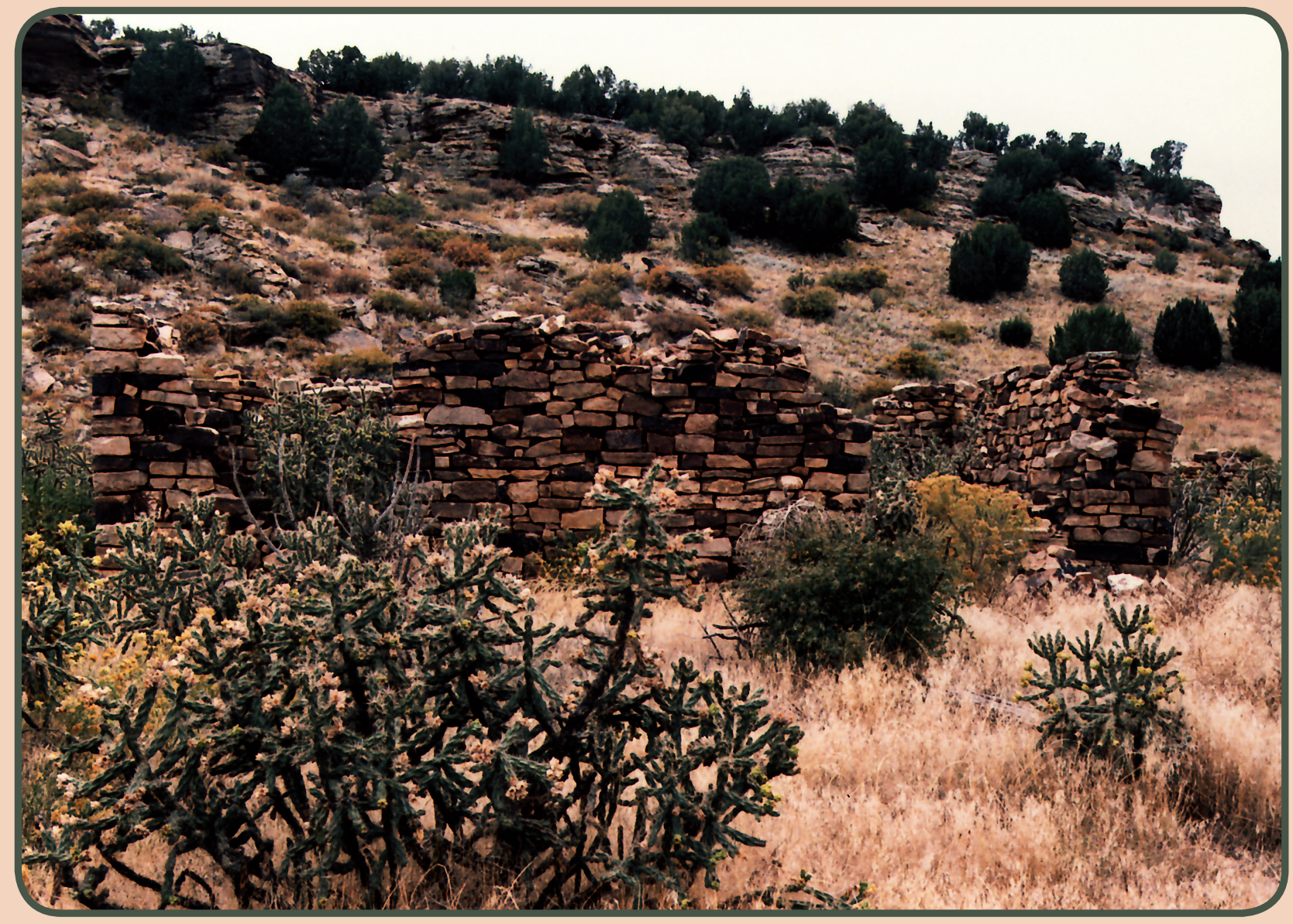

Circular 1314

U.S. Department of the Interior

U.S. Geological Survey 


\section{From Projectile Points to Microprocessors-The Influence of Some Industrial Minerals}

By Rhonda Driscoll

Circular 1314 


\section{U.S. Department of the Interior DIRK KEMPTHORNE, Secretary}

\section{U.S. Geological Survey \\ Mark D. Myers, Director}

\section{U.S. Geological Survey, Reston, Virginia: 2007}

For product and ordering information:

World Wide Web: http://www.usgs.gov/pubprod

Telephone: 1-888-ASK-USGS

For more information on the USGS--the Federal source for science about the Earth, its natural and living resources, natural hazards, and the environment:

World Wide Web: http://www.usgs.gov

Telephone: 1-888-ASK-USGS

Any use of trade, product, or firm names is for descriptive purposes only and does not imply endorsement by the U.S. Government.

Although this report is in the public domain, permission must be secured from the individual copyright owners to reproduce any copyrighted materials contained within this report.

Suggested citation:

Driscoll, Rhonda, 2007, From projectile points to microprocessors-The influence of some industrial minerals: U.S. Geological Survey Circular 1314, 26 p. 


\section{Contents}

Abstract
Introduction
The Versatile Nine
Bentonite-Montmorillonite
Halite (Salt)
Portland Cement
Peolite
Sarates
Stone Products -Aggregate, Dimension Stone, and Abrasives
Selected References.
Appendix. Domestic and World Production of Industrial Minerals

\section{Figures}

1. Photographs of Lower Paleolithic handaxes .....................................................................

2. Photograph of ancient Great Zimbabwe walls built of shaped

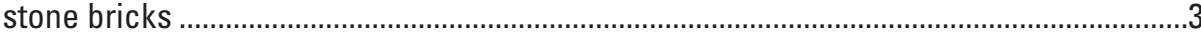

3. Aerial photograph of an Oakland, Calif., freeway system ……..........................................

4. Photograph of unusual gemmy blue bentonite crystals on natrolite ..................................3

5. Sketch conceptual model of montmorillonite soil crack development

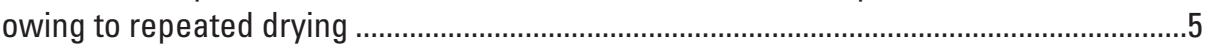

6. Photograph of pink halite (salt) crystal hand specimen ..................................................

7. Diagram showing salt solution mining .......................................................................

8. Aerial view of salt evaporation ponds in West Texas.......................................................

9. Drawing showing how, as concrete sets, particle nodes grow to connect with

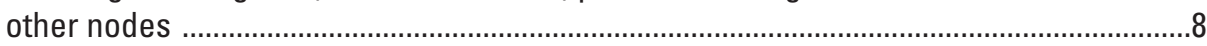

10. Photograph showing concrete masonry and cast products for

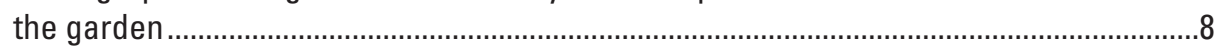

11. Aerial view of large concrete dam, Glen Canyon Dam, Colorado River..........................10

12. Sketch reconstruction of city of Babylon and photograph of excavated ruins ..............10

13. Photograph of a portion of the Great Wall near Yumenguan Pass, People's

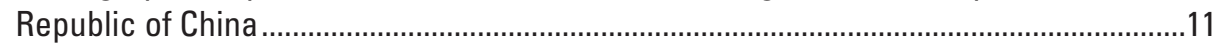

14. Photographs of Roman ruins at the seaport of Ostia ....................................................11

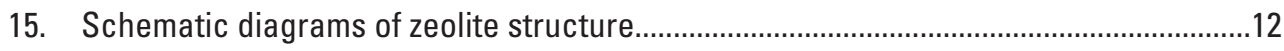

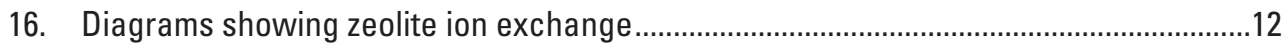

17-20. Photographs showing:

17. An example of the legendary "20-mule team" hauling borax.................................13

18. Colemanite crystals.....................................................................................14 
19. Flowering Indian paintbrush as an example of plant cycles aided by boron content in soil

20. Gypsum mine in badland topography near Salina, Utah

21. Sketch illustrating extent of wallboard use — from Earth to Moon, and

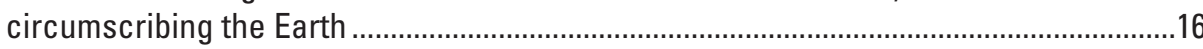

22. Photograph of synthetic silic on crystal in hand specimen ..........................................18

23. Photograph of sand as a golfer's menace on a golf course bunker ..............................18

24. Scanning electron microscope images of microcrystalline talc......................................20

25-27. Photographs showing:

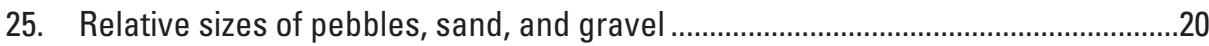

26. Uses and production of aggregate ………………............................................21

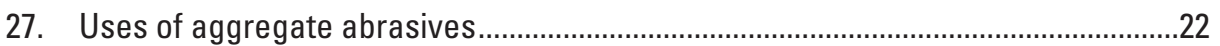




\title{
From Projectile Points to Microprocessors- The Influence of Some Industrial Minerals
}

\author{
By Rhonda Driscoll
}

\section{Abstract}

In the language of economic geology, Earth materials are classified as metallic ores, fuel minerals, gemstones, and industrial minerals. Most people know that metallic ores yield shiny, conductive, ductile elements such as copper, iron, or gold. And nearly everyone understands that energy-producing coals constitute a fuel mineral. Likewise, dazzling rubies and rare sapphires are universally recognized as gemstones. The fourth group, industrial minerals, is largely unknown to the general public, even though industrial minerals are as essential to daily life as metals and fuel minerals. This report examines in brief the occurrence and practical uses of nine industrial minerals, selected for general interest as well as their importance. The minerals profiled in this report represent only a few of the more than 50 industrial minerals that shape human culture.

\section{Introduction}

Since the time of early humans, natural Earth materials have contributed to the species' survival and progress. Principal among these natural materials have been stone, salt, and, with the advance of time, clay, gypsum, and dozens more nonmetallic, nonfuel substances known today as industrial minerals.

In the beginning primitive hunters clobbered prey with rocks. Later, men stalked food with carefully crafted stone weapons, such as spear points and dart tips (fig. 1).

Later still, humans discovered a method of food preservation using salt. They built food storage structures and family dwellings using adobe clay and stones (fig. 2). And when the hunters became farmers, they devised irrigation systems by lining shallow diversion canals with native rock.

As towns and city centers appeared, so too did levees, paved streets, administrative buildings, and tiled baths - the construction of which derived from regional limestone, sandstone, granite, clay, and other available rock material.

Fast forward a few thousand years and marvel at seemingly limitless industrial minerals applications. From paints to fuel additives, feedlots to fish farms, freeways to nuclear reactors, industrial minerals are at the center of modern affluent existence (fig. 3).

As you read you will recognize a truth: most of what you do or have or rely on can be connected to industrial minerals.

\section{The Versatile Nine}

Industrial minerals can be found in everyday consumer goods such as house paint and pet products. They are also present in uncommon, special purpose products like conductive plastics (graphite) and solar cell electric power generators (tellurium). This report examines only 9 of the approximately 50 most utilized industrial minerals. These nine minerals are among the most abundant in their natural state and are most likely to be found in products and processes worldwide.

\section{Bentonite-Montmorillonite}

Discovered in 1890 near Fort Benton, Wyo., bentonite is a rock that contains colloidal silica and assorted clay minerals including montmorillonite. Montmorillonite, whose chemical formula is $(\mathrm{Na})_{0.7}\left(\mathrm{Al}_{3.3} \mathrm{Mg}_{0.7}\right) \mathrm{Si}_{8} \mathrm{O}_{20}(\mathrm{OH})_{4} \cdot \mathrm{nH}_{2} \mathrm{O}$, belongs to a group of clay minerals referred to as smectites-minerals which tend to swell when wet and shrink when dry (fig. 4).

Swelling occurs when water penetrates and enlarges the interlayered molecular spaces of the smectite structure. Shrinking occurs when detached water molecules leave voids in the smectite lattice, causing the structure to collapse. It is this alternate swelling-shrinking property that makes bentonite-montmorillonite both a constructive and a destructive natural material.

As a constructive agent, bentonite has many industrial applications. It is used by oil, gas, and water extraction industries as a drilling mud. In a semi-fluid state bentonite is extruded through the drill bit to keep the bit cool and lubricated as it bores through rocks into a petroleum deposit or an aquifer. Trailing the drill shaft is a thin stream of montmorillonite-fill. This wet fill expands into cracks and fractures along the wall of the borehole, adding stability and strength. Later, when a well so constructed is exhausted, industry once again relies on bentonite. Clay-rich bentonite chips are loaded into 

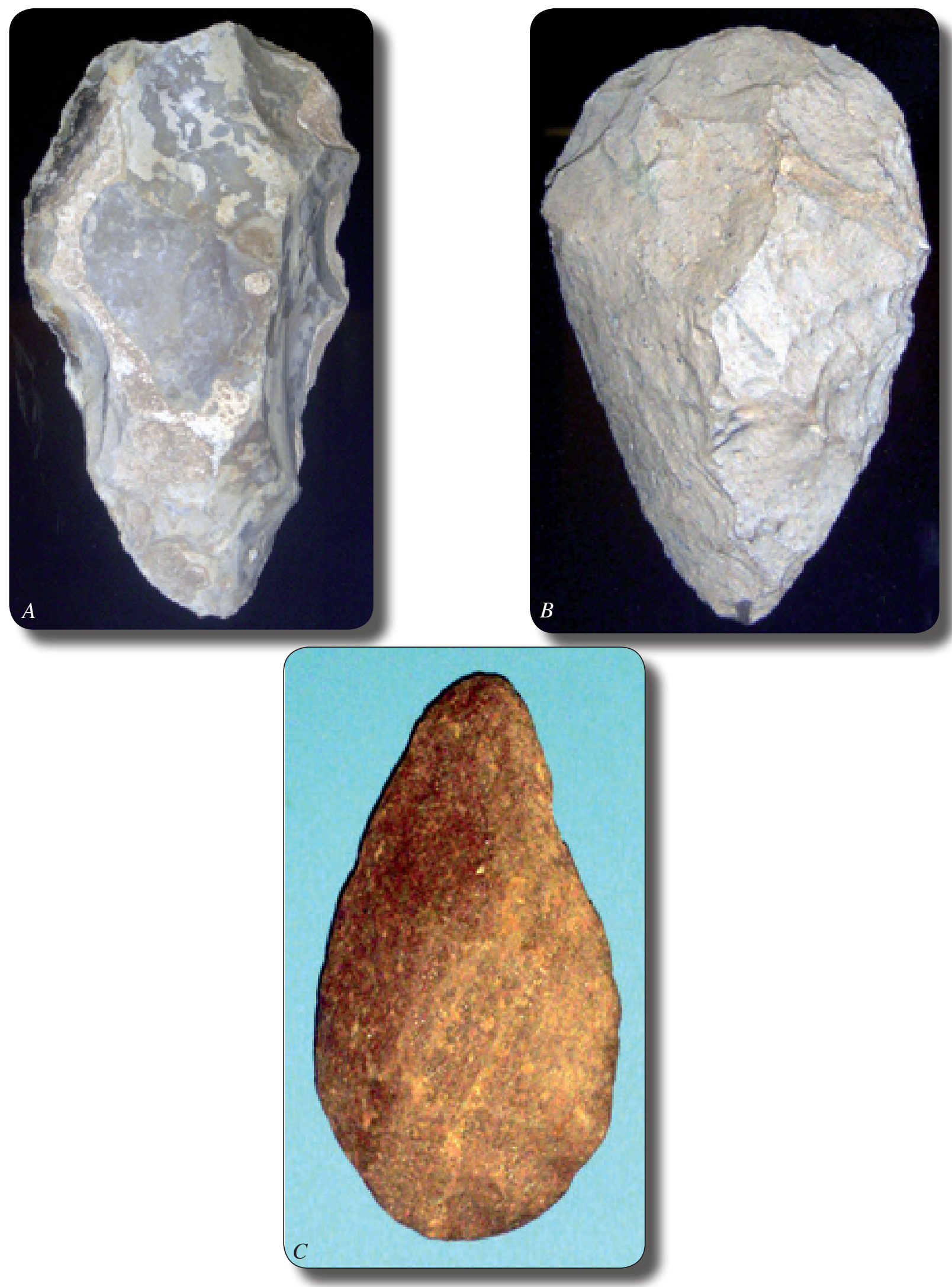

Figure 1. Lower Paleolithic handaxes. A, Large Acheulian handaxe (Lower Paleolithic, 2,000,000 to 200,000 B.C.E.), $13 \mathrm{~cm}$ long, culture unknown. $B$, Large Acheulian handaxe, $17 \mathrm{~cm}$ long, from Maghreb (the region of northwest Africa including Morocco, Algeria, and Tunisia). C, Acheulian handaxe, $11 \mathrm{~cm}$ long, from Kasai, Democratic Republic of the Congo, Central Africa. Photographs Wladyslaw Kowalski, Pennsylvania State University. 


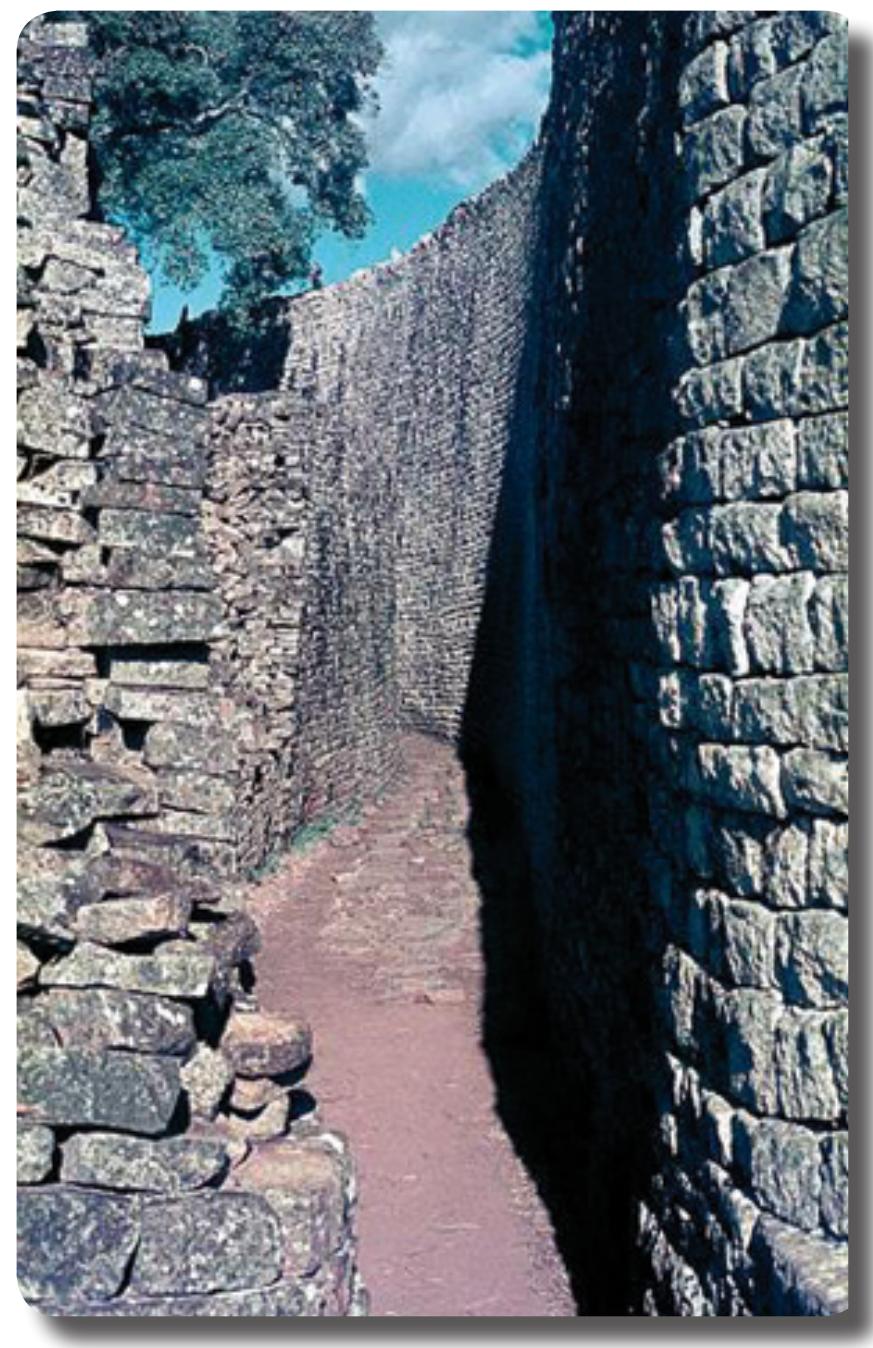

Figure 2. Ancient Great Zimbabwe walls built of shaped stone brick, near Masvingo, Zimbabwe. The walls were constructed around 1200 B.C.E. Photograph A.J. Mandolesi, from the American Geological Institute image library. Image source Earth Science World Image Bank http://www.earthscienceworld.org/ images.

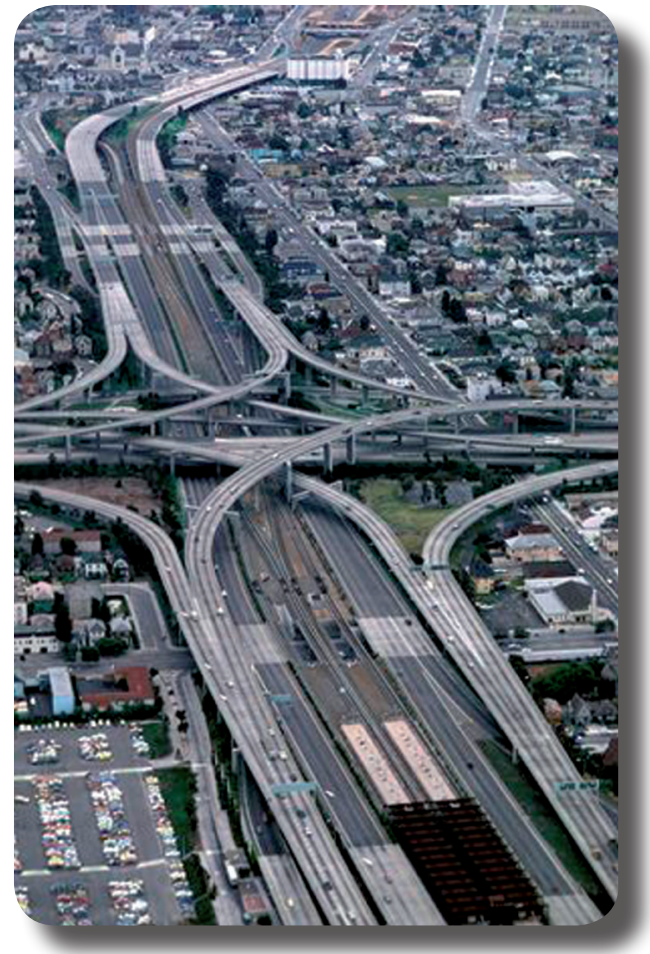

Figure 3. Aerial view of an Oakland, Calif., freeway system; date unknown. Photograph Michael Collier, from the American Geological Institute image library. Image source Earth Science World Image Bank http://www. earthscienceworld.org/images.

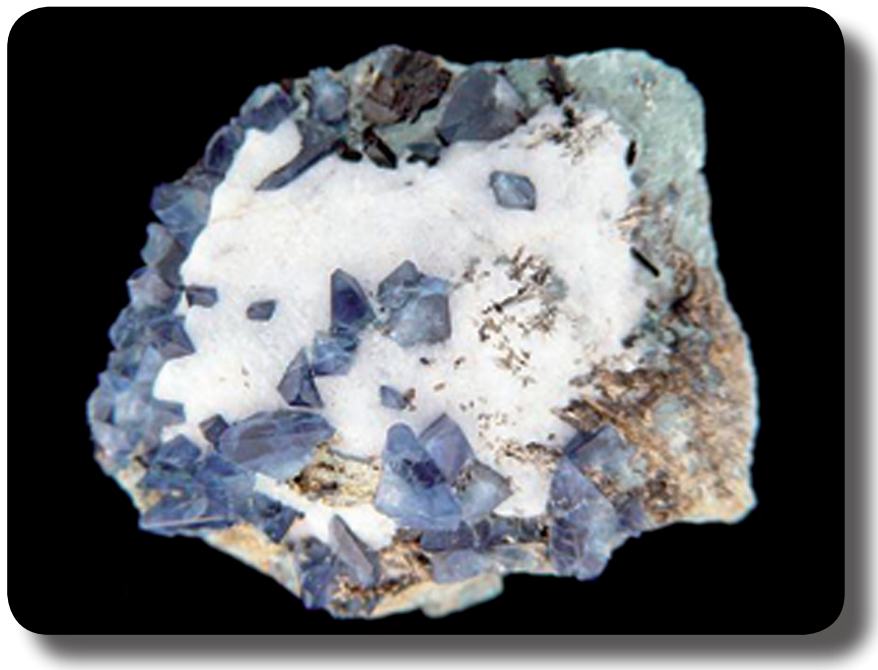

Figure 4. Uncommonly gemmy blue bentonite crystals on natrolite. Bentonite usually occurs as a fine-grained gray to graywhite mass. Photograph by Stonetrust, Inc., from the American Geological Institute image library. Image source Earth Science World Image Bank http://www.earthscienceworld.org/images. 
the decommissioned borehole where, upon wetting, they swell to form a permanent solid clay seal and contamination barrier within and outside the borehole.

The metals industry has also discovered uses for bentonite. In a process called green sand casting, sand of uniform composition and size is blended with coal dust, cellulose, silica flour, bentonite, and water. In a moist state the sand mixture is squeezed, or molded, into hollow shapes into which molten metals are poured. Bentonite in the sand mixture serves two functions: in a moist or hydrated state, bentonite swells to hold the sand mold together, and in a dry or dehydrated state, bentonite acts as a thermal expansion buffer by absorbing excess heat that would otherwise distort the mold.

The paper industry and the pet products industry have also found practical applications for bentonite. The former uses sodium bentonite to capture effluent and flocculent in paper-making processes, while the latter adds montmorillonite clay to commercial cat and bird litters. Because of its moisture absorbent property, bentonite-montmorillonite can wick up unwanted, impure, and malodorous fluids.

Bentonite-montmorillonite has even found its way onto feedlots and croplands. It is used as a binder in livestock food pellets and as a carrier for herbicides and pesticides applied to cultivated soils. In addition, bentonite soil applications can improve soil properties such as aeration, permeability, holding capacity, and nutrient uptake. Improvements such as these can be especially valuable in areas where rainfall amounts are minimal. During dry cycles the bentonite dehydrates, releasing moisture and nutrient solutions to root soil horizons.

The benefits of bentonite-montmorillonite are indisputable, but it is the destructive quality of the mineral that causes the most concern for land developers and homeowners. Because bentonite-montmorillonite expands and contracts (hydrates and dehydrates) in changing moisture conditions, it can ruin building foundations and sidewalks. It can also damage costly landscaping and subsurface sewage and communication systems. As rainwater soaks into underlying bentonite soils, absorption and expansion occur. Expanding clay can swell to several times its dry volume, pushing against concrete foundations, conduits, and cable lines with enormous force. Over time, this expansion pressure can produce cracks or distortions in concrete support walls; it can sever PVC pipe, fiber-optic cables, and critical plant roots.

Conversely, dry weather can dehydrate, or shrink, bentonite soils. Shrinkage produces voids in the soil into which sod, basements, driveways, or steel cables collapse by inches, or even feet! Figure 5 illustrates part of the story. Structural repair costs associated with active bentonite-montmorillonite soils are in the billions of dollars annually.

Despite its destructive potential, bentonite-montmorillonite contributes to modern industries and modern comforts in ways generally unknown and unacknowledged.

\section{Halite (Salt)}

Halite, or sodium chloride $(\mathrm{NaCl})$, is a critical industrial mineral. It occurs naturally as cubic crystals (fig. 6) in underground domes or bedded sedimentary layers, and on the Earth's surface as the residue of ancient seas.

Halite is much more than the white granular food seasoning used worldwide. Historically, it was a soldier's pay, a warlord's leverage, a nomad's rank, and a tribesman's talisman. Today's uses are just as practical. Nowhere is this practicality more evident than in the chemicals industry, the largest consumer of salt. A short list of the more familiar chemicals produced from a sodium chloride base includes:

- Chlorine $(\mathrm{Cl})$ - a bleaching product, a germicide, a compound element

- Caustic soda ( $\mathrm{NaOH}$, sodium hydroxide) - a neutralizing agent in the petroleum, pulp, paper, and alumina (aluminum oxide, $\mathrm{Al}_{2} \mathrm{O}_{3}$, an ingredient of ceramics and insulation) industries

- Sodium chlorate $\left(\mathrm{NaClO}_{3}\right)$ - a pesticide, herbicide, and oxidizer (a substance that supports the combustion of fuel)

- Sodium sulfate $\left(\mathrm{Na}_{2} \mathrm{SO}_{4}\right)$ - used in the manufacture of soaps and detergents

- Hydrochloric acid ( $\mathrm{HCl}$ - — rust- and scale-removal agent, a component of batteries and fireworks.

To obtain these and other derivative compounds, the two components of halite - sodium $\left(\mathrm{Na}^{+}\right)$and chlorine $\left(\mathrm{Cl}^{-}\right)$-must be separated and concentrated. This is accomplished by dissolving salt in an oxidized solution (separation). Once the salt is dissolved, the solution is passed through a magnetic filtration system that captures the chlorine atoms (concentration). The sodium or chlorine concentrate can then be mixed with other elements to create new chemical compounds.

The use of salt is by no means confined to the production of chemicals. Salt is used as a dietary supplement for livestock and poultry. Agricultural studies confirm that salt contributes to the good health and optimum growth of feedlot and freeranging food animals.

Livestock aren't the only beneficiaries of salt. Urban commuters travel with more confidence on wintertime roads treated with rock salt. Salt is still the most commonly used roadway de-icer. As it converts solid ice to liquid water, its own solid state is unaffected. It facilitates the melting process by increasing the kinetic energy of $\mathrm{H}_{2} \mathrm{O}$ molecules. That it can do so to a maximum low temperature of $15^{\circ} \mathrm{F}\left(-9^{\circ} \mathrm{C}\right)$ makes salt one of the more fascinating industrial minerals (About..., 2004).

Salt can affect water in another important way. It can be used as a water softener or conditioner. "Hard" water contains excess dissolved calcium $(\mathrm{Ca})$ and (or) magnesium $(\mathrm{Mg})$. When salt is added to hard water, it behaves like a trap, 


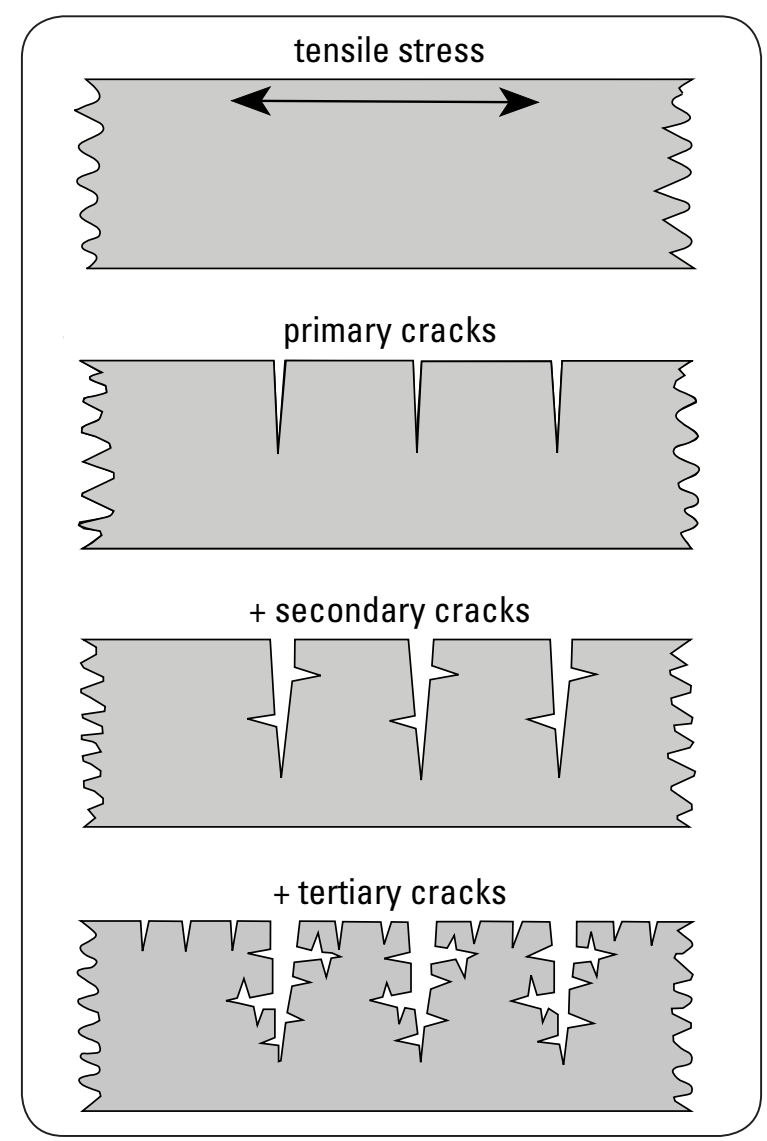

Figure 5. Conceptual model of montmorillonite soil crack development owing to repeated drying. (Modified from Dexter, 1998.)

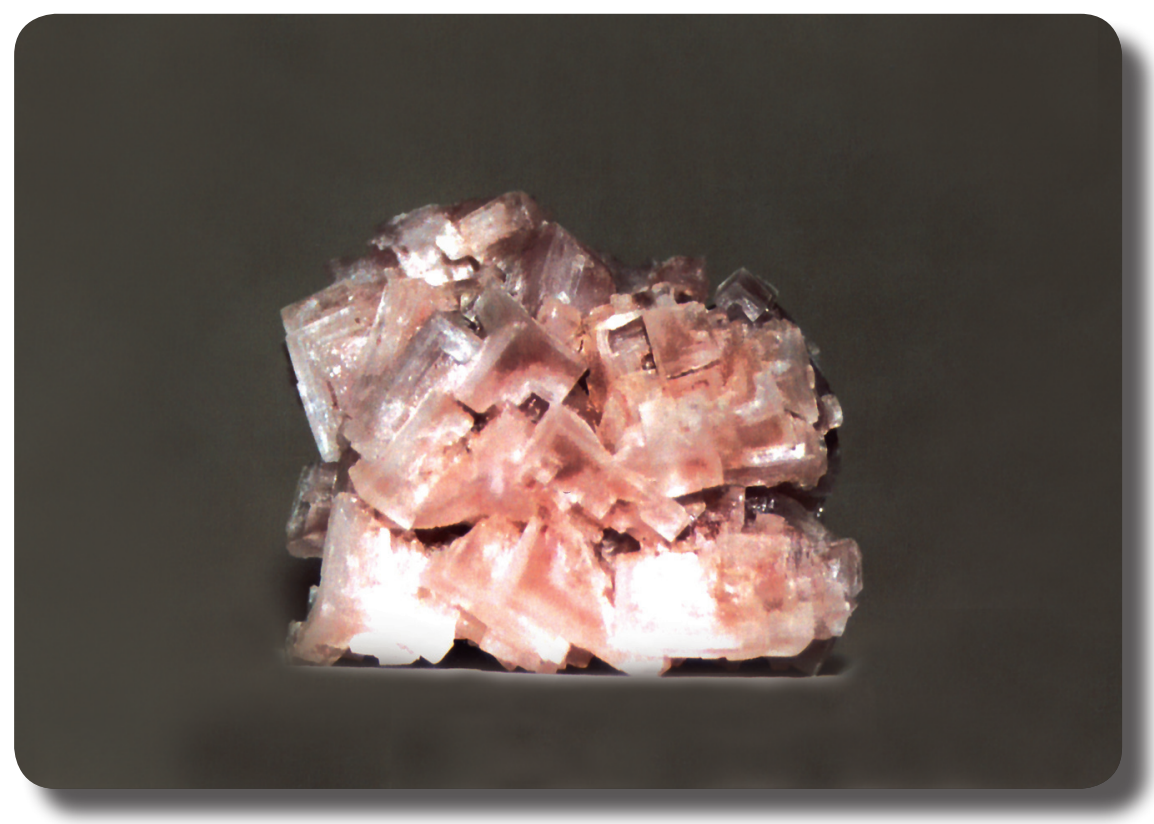

Figure 6. Pink halite (salt) crystal measuring $3 \times 4 \times 4$ in.; specimen locality unknown. Photograph by author. 
snaring calcium and magnesium ions. By capturing "hard" calcium and magnesium atoms, salt becomes an economical water-softening agent. "Soft" water requires less detergent and soap for laundering, cleaning, and bathing.

In dry and drought-stricken areas, sodium chloride is distributed in the warm troposphere to produce rain. When ideal stratus clouds form at low altitude, aircraft release salt into targeted portions of the cloud mass. Moisture droplets in the cloud layer collect on the salt grains (a hygroscopic attraction) until the combined weight of the droplets and salt forces their fall to the Earth's surface (NAWC, 2003).

Every day, Earth's approximately six billion people depend on salt. In the past 100 years, annual global salt production has increased from 10 million tons to 200 million tons (U.S. Geological Survey, 2004). North America produces about one-quarter of the world's salt.

Salt is produced by four methods:

- Solution mining: Water is injected into an underground salt bed or salt dome, which dissolves the salt and produces a brine (fig. 7). The brine is pumped to an aboveground evaporation site. From there, concentrated "dry salt" is transported to chemical plants.

- Solar evaporation of sea water or saline lake water: Natural sun and wind evaporation takes place in brine ponds until salt crystals appear (fig. 8). Crystallization begins at a sodium chloride concentration of 25.8 percent.

- Vacuum pan evaporation: A concentrated brine solution is chemically treated to remove impurities such as magnesium $(\mathrm{Mg})$, calcium $(\mathrm{Ca})$, and sulfate $\left(\mathrm{SO}_{4}{ }^{2-}\right)$. The concentrate is ultra-dried using a centrifuge, vacuum, or kiln. The resulting food grade salt is then fortified with iodine (I) to prevent iodine deficiency disorders such as goiter, dwarfism, and certain types of mental retardation.

- Deep shaft (rock salt mining): In a typical underground rock salt mine, heavy machinery cuts a narrow corridor through a section of a deposit. Holes are drilled into the walls of the corridor and packed with dynamite; when the charge is detonated, the corridor walls collapse. Miners operating electric shovels then move in to scoop the salt onto train cars or dump trucks, gradually carving caverns, or rooms, supported by salt pillars. The extracted salt is hauled to below- or aboveground crushers. Once crushed, the salt is passed through giant sieves. A system of conveyors moves the salt to size-specific piles. Commercial carriers arrive to load and transport the salt to outlying plants for additional treatment or storage.

To locate underground salt deposits, energy waves created by seismometers are sent underground. The waves are reflected back to surface recorders called geophones. The recorders capture data signals that are translated into "maps" or profiles of subsurface features. This method of finding and profiling salt deposits is called reflection seismography. Seismographs reveal either salt domes called diapirs, or salt beds buried by sedimentary layers. Salt beds range from tens of feet to several thousands of feet thick. Domes are often more than 1 mile in diameter and 15,000 feet in vertical length.

To describe a friend as "salt of the Earth" is high praise indeed. It suggests value, versatility, and complexity.

\section{Portland Cement}

Portland cement itself is not an industrial mineral. It is a manufactured product consisting of limestone, shale, and (or) other naturally occurring materials. All Portland cements are discrete compounds-stand-alone masonry material. But, when blended with aggregate, Portland cement becomes concrete. A typical mixture of concrete contains 11 percent Portland cement, 41 percent coarse aggregate, 20 percent sand, 6 percent air, and 16 percent water (W.H. Langer, written commun., 2005). When water is added to the mix, a node (black semi-triangle, left side of fig. 9) begins to form on the surface of each cement or aggregate particle (irregular outline, fig. 9). The node grows, or expands, to link up with nodes of other particles until the concrete exhibits a standard stiffness (Portland Cement Association, 2004). The concrete is then poured, compacted, floated, trowelled, and cured. What many people don't know is that curing doesn't end when concrete is dry and appears impenetrable. Curing is a process that continues for the life of the concrete-as it ages concrete gets stronger, albeit at a very slow rate.

Types of concrete include:

- Ready-mixed- $3 / 4$ of all concrete shuttled in the familiar revolving drum trucks (van Oss, 2004)

- Pre-cast-concrete bricks, bridge girders, and structural components

- Concrete masonry - cast in many shapes, configurations, colors, and textures to satisfy architectural design (fig. 10)

- Cement-based materials such as mortar, grout, and terrazzo

- Advanced products that incorporate fibers and special aggregates to create roofing tiles, sidings, and countertops.

A classification reference developed by the American Society for Testing and Materials (ASTM International, 2004) lists types of Portland cements and their recommended uses:

- Type I Portland cement is a general-purpose construction cement used in buildings, bridges, floors, and pavements. 


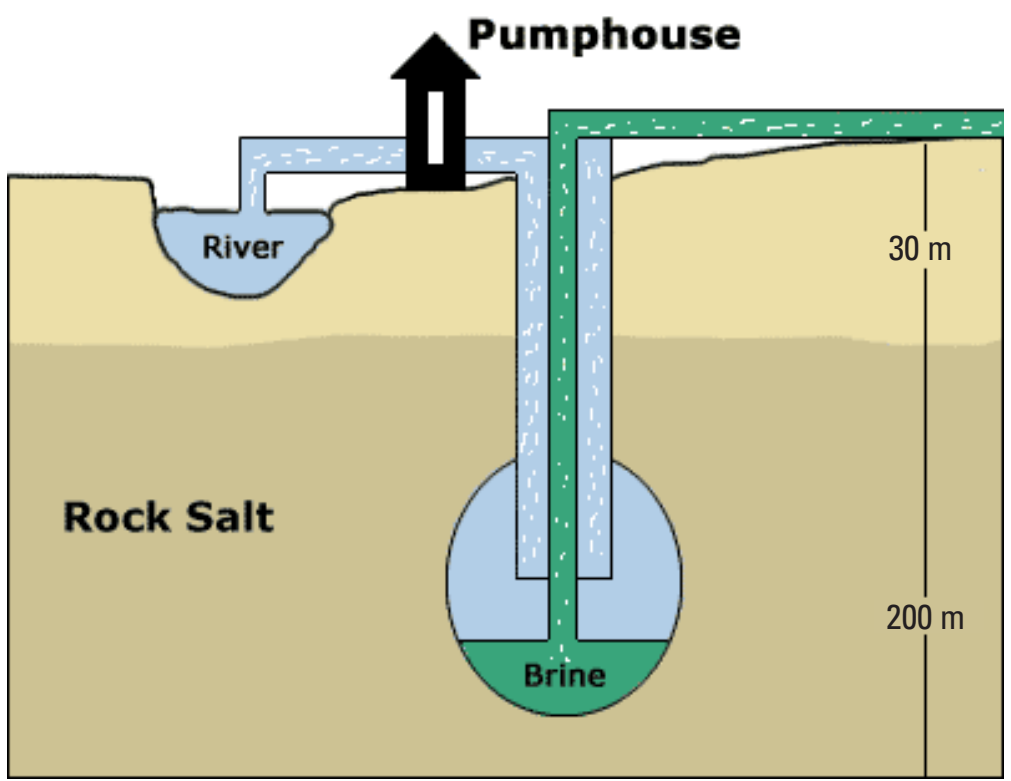

Figure 7. Solution mining. Pressurized water is pumped into underground salt deposits through a borehole; the dissolved salt, called brine, is pumped to a topside processing plant. Diagram courtesy www.saltsense.co.uk.

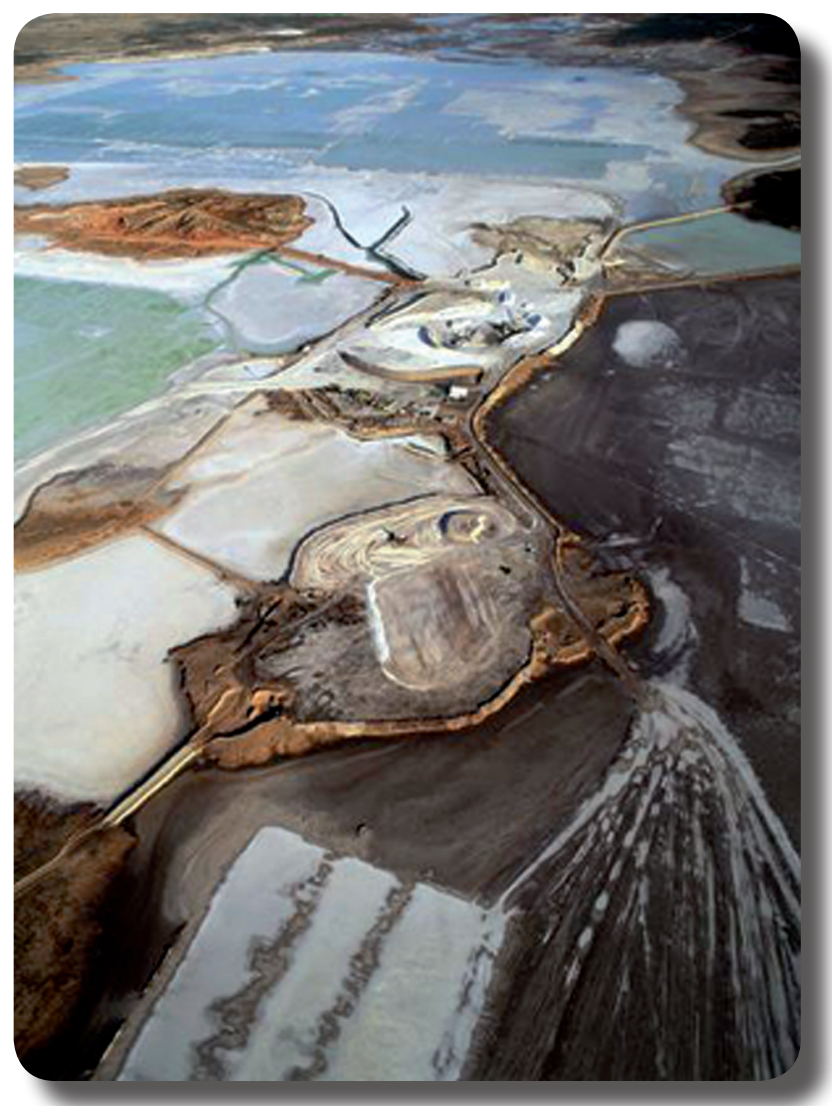

Figure 8. Aerial view of salt evaporation ponds in West Texas. Photograph Michael Collier, from the American Geological Institute image library. Image source Earth Science World Image Bank http://www.earthscienceworld. org/images. 


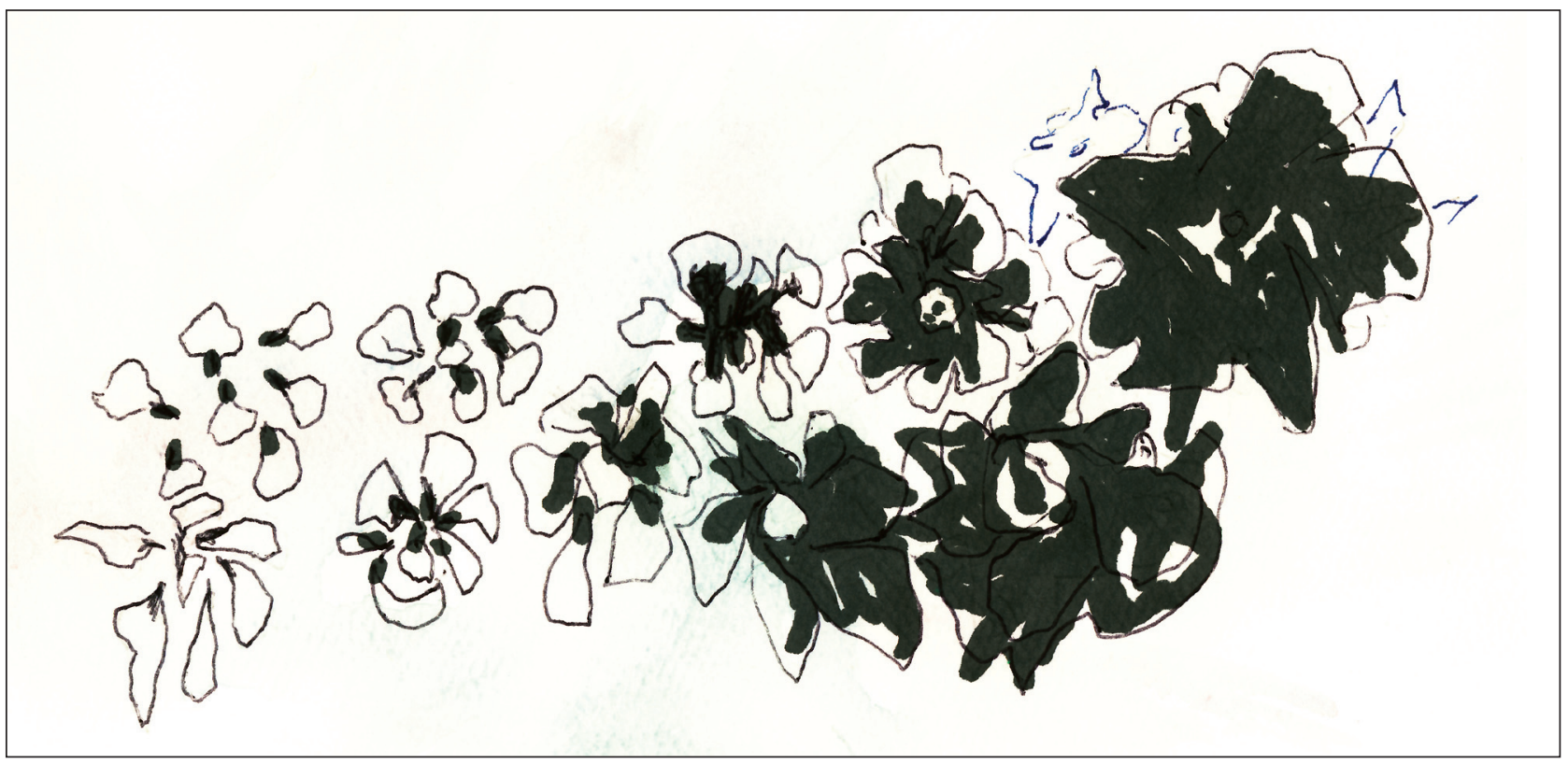

Figure 9. Particle nodes grow to connect with other nodes within setting concrete, forming a dense mass. Ink illustration by John Driscoll.

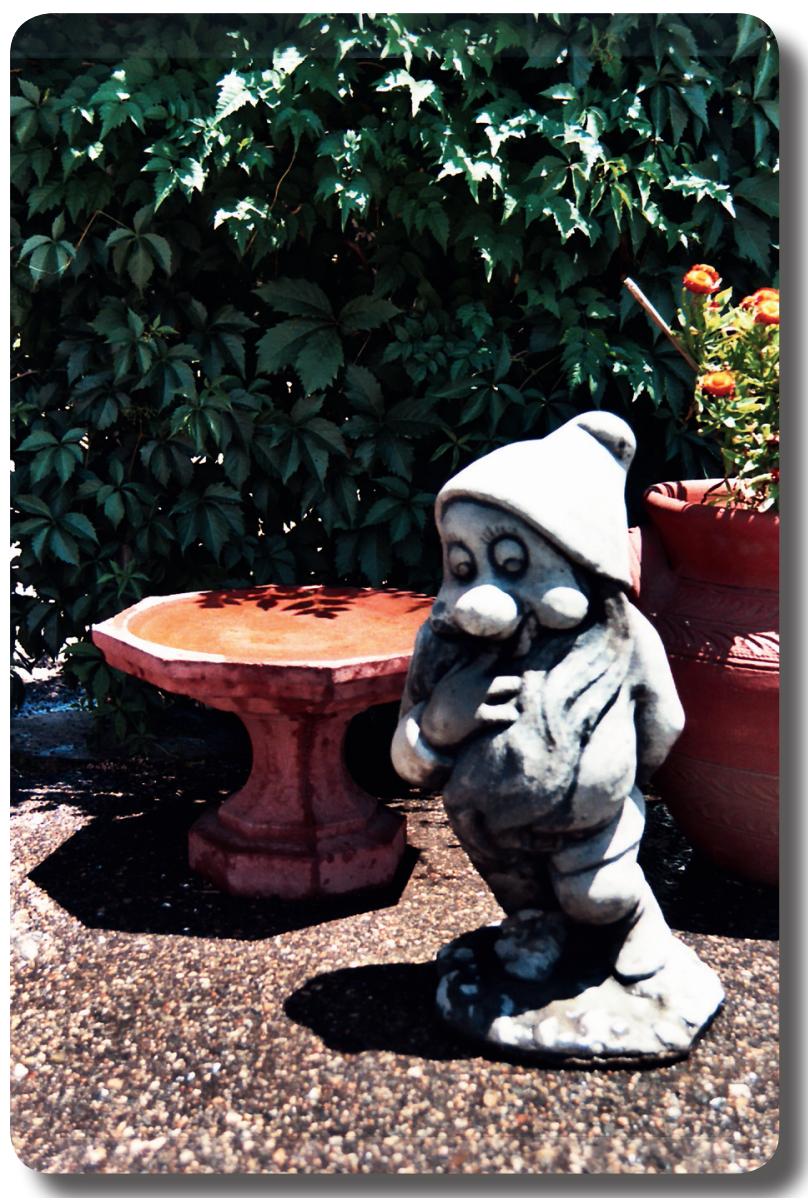

Figure 10. Red concrete masonry birdbath and flower pot, and cast concrete garden elf without added color. Photograph by author. 
- Type II has been developed for resistance to minor sulfate $\left(\mathrm{SO}_{4}^{2-}\right.$, a salt of sulfuric acid $\left.\left(\mathrm{H}_{2} \mathrm{SO}_{4}\right)\right)$ present in some building projects or processing environments.

- Type III is used when the combination of rapid set and strength gain is required.

- Type IV develops strength at a slow rate and generates low heat. It is used in massive concrete structures such as dams (fig. 11).

- Type $\mathrm{V}$ is used for masonry structures that are exposed to very high levels of sulfate derived from soils or ground water.

Though all Portland cement hardens under water, not all are suitable for underwater structures. A specialty mixture that includes Portland cement, granulated blast furnace slag, fly ash, pozzolana (siliceous volcanic ash), and silica fume (a byproduct of silicon metal production) can be poured directly into submerged forms.

Expansive Portland is yet another special application cement. As its name implies, this cement expands slightly as it hardens. Used almost exclusively in bridge deck construction, expansive cement reduces the occurrence of drying-shrinkage cracks. It also contributes to the overall tensile, or tension, strength of the elevated deck.

Before the discovery of Portland cement in 1824, cements, or mortars, of varying composition were used to build structures. A gypsum mortar was used in the construction of some Egyptian pyramids. The ancient Babylonians used lime-based mortars to build fortifications and irrigation canals; the Chinese constructed parts of the Great Wall with a mud-and-straw mortar (figs. 12, 13).

But it was the Romans (c. 300 C.E.) whose mortar formulas were the most innovative. Lime, sand, pozzolana, animal fat, milk, and blood were all used as admixtures. The Roman Empire succeeded, in large part, because of Roman cement technology (fig. 14). Evidence of their expertise is found in a letter from a provincial governor to the emperor: Around 112 C.E. [Common Era; formerly A.D.], Roman Emperor Trajan (98-117 C.E.) appointed Pliny the Younger as governor of Bythinia (present-day northern Turkey). Upon his arrival in the Bythinian capital of Nicomedia, Pliny discovered a city in a state of disrepair and a guild class practiced in larceny. Many public buildings were dilapidated; public works projects were incomplete and over budget. In correspondence with Trajan, Pliny described, among other construction fiascos, a gymnasium project: “***the architect asserts that the walls, although twenty-two feet thick, cannot bear the weight placed upon them, because they have not been put together with cement***" (Davis, 1912).

Like all educated Roman citizens of the time, Pliny appreciated the strength of cement. Today, advances in chemistry as well as in computer simulation continue to foster appreciation for this durable admixture.

The importance of Portland cement cannot be exaggerated. It is used everywhere. Science and industry have invested untold billions and conducted countless experiments in an ongoing effort to create inexpensive, long-lasting, conditionspecific cements and concretes-terra firma synthesized!

\section{Zeolite}

Zeolites, like clay minerals, are alumino-silicates. Unlike clays, which have a two-dimensional layered structure, zeolites have a three-dimensional structure similar to a honeycomb (fig. 15). This framework of interconnected tunnels and cells allows for free movement of gases and solutions through the mineral interior. And, because the stacked tunnels have nearly uniform dimensions, zeolites can act as molecular sieves, screening molecules of varying size and shape. It is this "screening" property that makes zeolites a most important and wonderful industrial mineral.

To understand the phenomenon of molecular sieving, a few terms and concepts have to be explained. The first of these is ions-positively or negatively charged atoms or molecules. Cations, such as $\mathrm{Na}^{+}$, are positively charged ions. Anions are negatively charged. An example of an anion is $\mathrm{Cl}^{-}$. Next is ion exchange - a chemical reaction in which equal numbers of ions of identical charge and similar shape and size are exchanged between two substances. Zeolite minerals have a superior ion exchange capacity. As ionized fluids or gases diffuse in and out of the zeolite structure, ion exchange occurs. Thus, for example, potassium $\left(\mathrm{K}^{+}\right)$and sodium $\left(\mathrm{Na}^{+}\right)$ions from a zeolite framework can be exchanged for ammonium ions $\left(\mathrm{NH}_{4}^{+}\right)$present in a soil. The ammonium cations fit neatly into the zeolite structure, while the liberated potassium and sodium cations are dispersed throughout the soil as a plant micronutrient. The charge balance and structural integrity of the zeolite are preserved, and potentially toxic ammonium is removed from the soil and replaced by an essential plant nutrient (fig. 16).

This exchange process is called "sieving." The capacity of zeolite minerals to selectively exchange ions in almost any environment, without damage to its own porous structure, makes it an ideal mineral for many industrial and commercial applications. One such application can be found in the commercial meats industry. Beef, pork, and poultry producers rely on zeolite to control ammonia $\left(\mathrm{NH}_{3}\right)$ and hydrogen sulfide $\left(\mathrm{H}_{2} \mathrm{~S}\right)$, two unpleasant gases associated with the decomposition of organic waste. By dusting approximately $1 \mathrm{lb}$ of zeolite over a square foot of animal waste pile, offensive gases can be minimized or eliminated by cation exchange. The zeolite can then be transferred from the waste enclosure to cultivated acreage where it slowly releases the nitrogen $(\mathrm{N})$ component of the ammonium $\left(\mathrm{NH}_{4}^{+}\right)$to the nutrient uptake system of plants.

Zeolite has also been adapted to aquaculture. In fish rearing environments, $\mathrm{NH}_{4}^{+}$toxicity (from fish excrement) can be reduced by adding a zeolite substrate to the water filtering system. The zeolite substrate provides a second benefit-that of a constructive bacteria nursery. Some bacteria populations convert $\mathrm{NH}_{4}^{+}$(a weak base also known as ammonia water or 


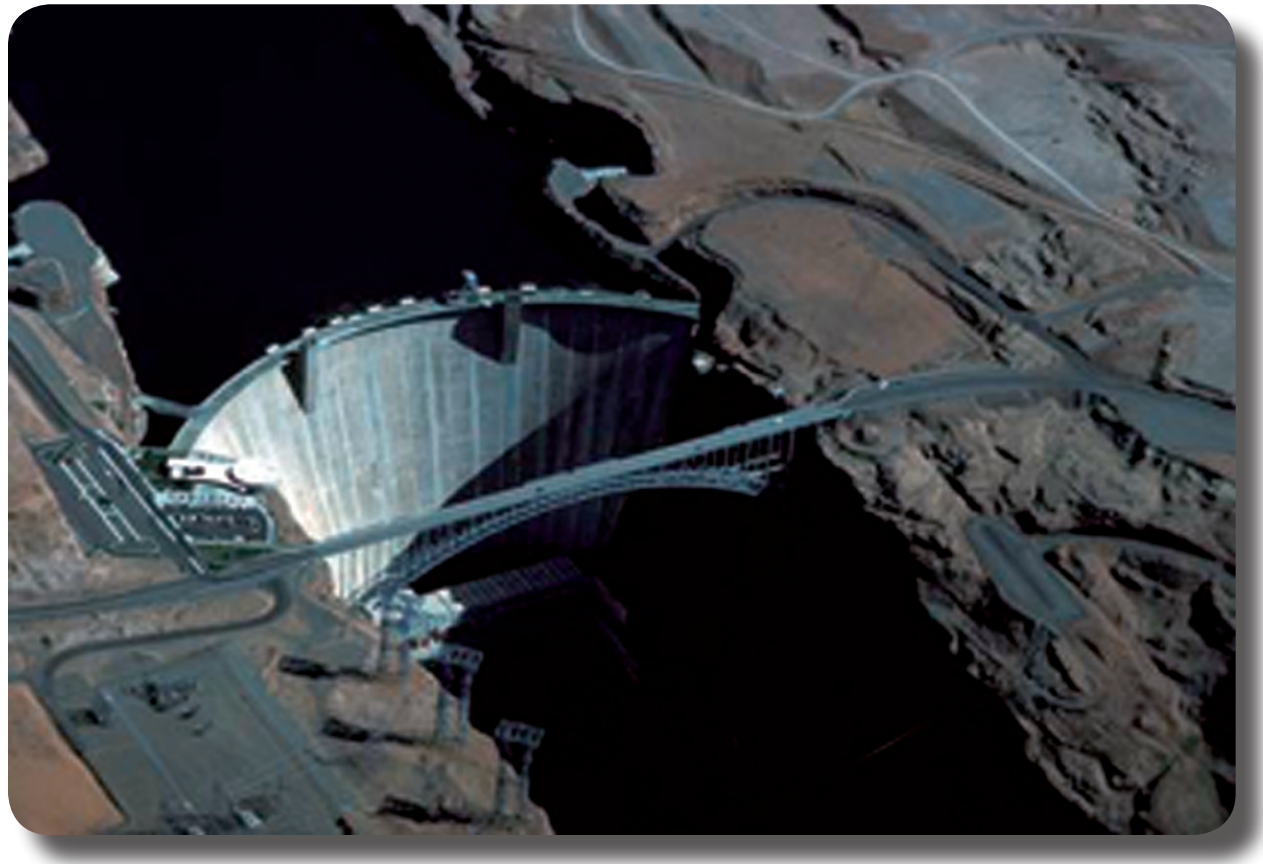

Figure 11. Aerial view of Glen Canyon Dam on the Colorado River. Photograph by Michael Collier, from the American Geological Institute image library. Image source Earth Science World Image Bank http://www.earthscienceworld.org/images.

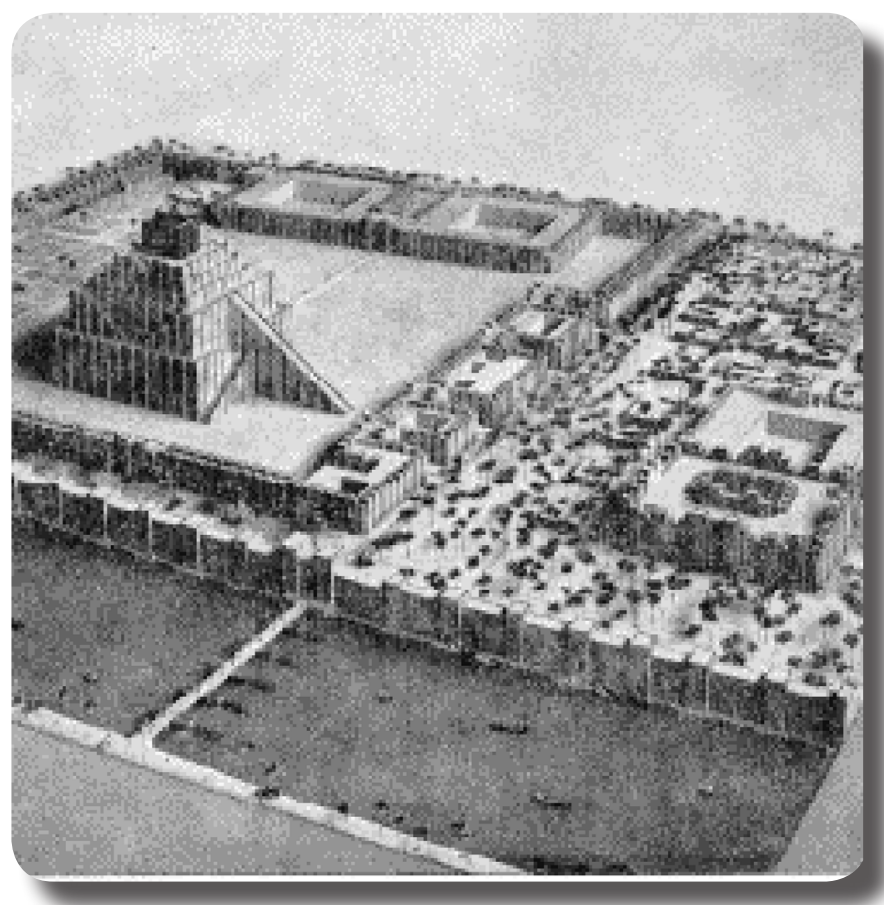

A

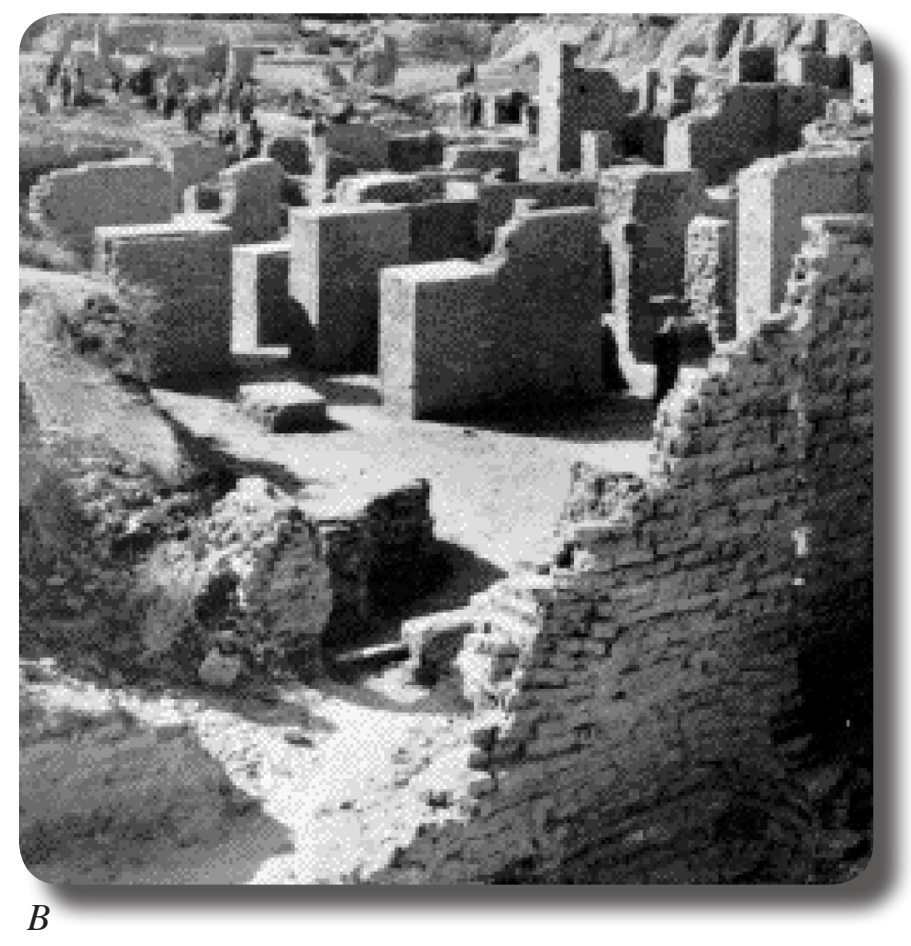

Figure 12. Construction in the ancient city of Babylon. $A$, artist reconstruction of the city; $B$, excavated ruins of the city. Photographs Fairfield University, www.fairfield.edu. 


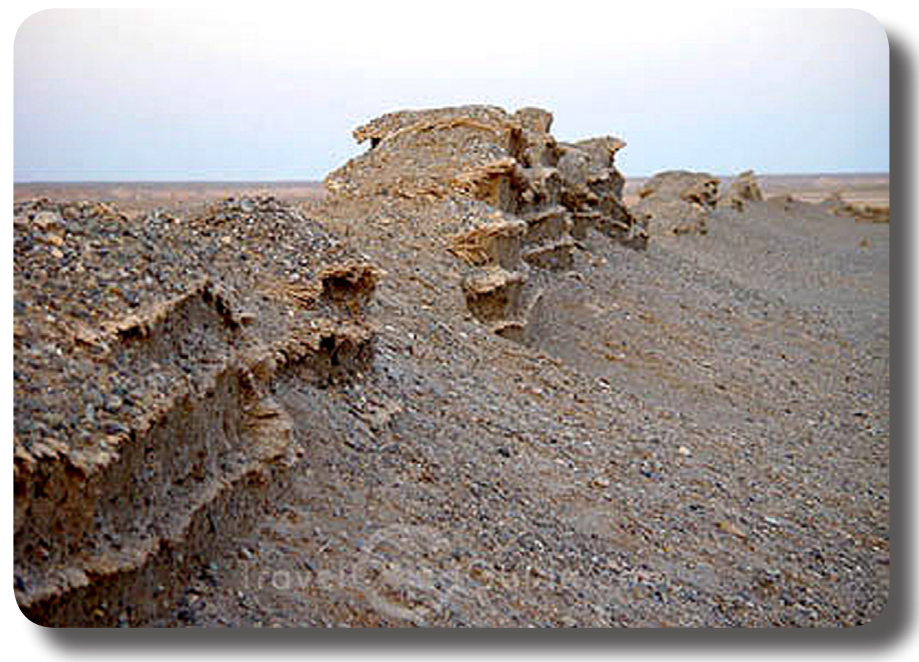

Figure 13. A view of a nearly forgotten portion of the Great Wall near Yumenguan Pass, People's Republic of China; a relic of the Han Dynasty built of reeds, tamarisk twigs, sand, and mud. Photograph www.travelchinaguide.com.
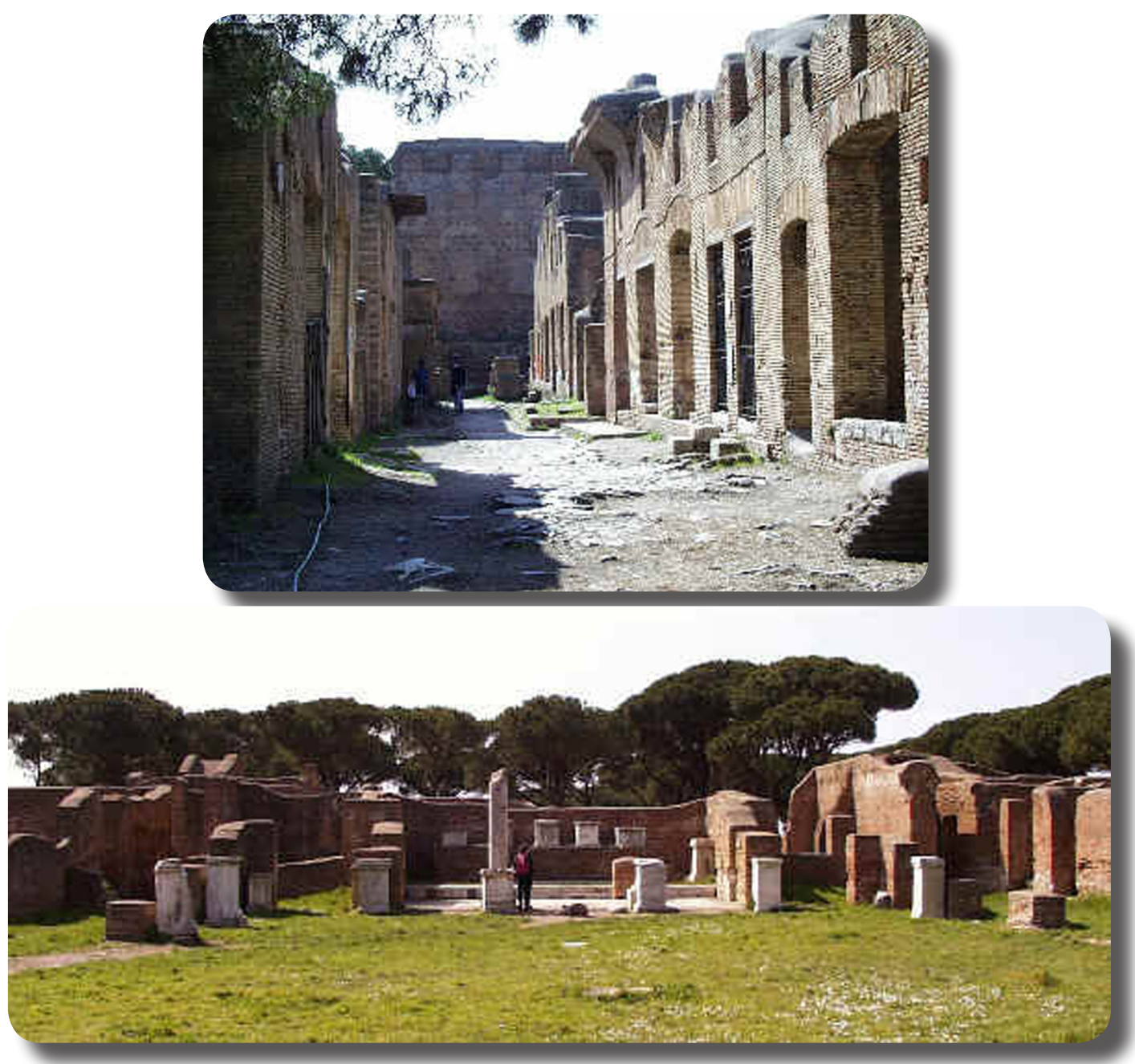

Figure 14. Roman ruins at the seaport of Ostia. Apartments located near the baths (top); firefighters' barracks near the harbor (bottom). Ostia had 100,000 inhabitants at its peak. The emperor Trajan spent considerable money enlarging and improving 0stia. Photograph David Chaszar, www.ancient-rome.tripod.com. 


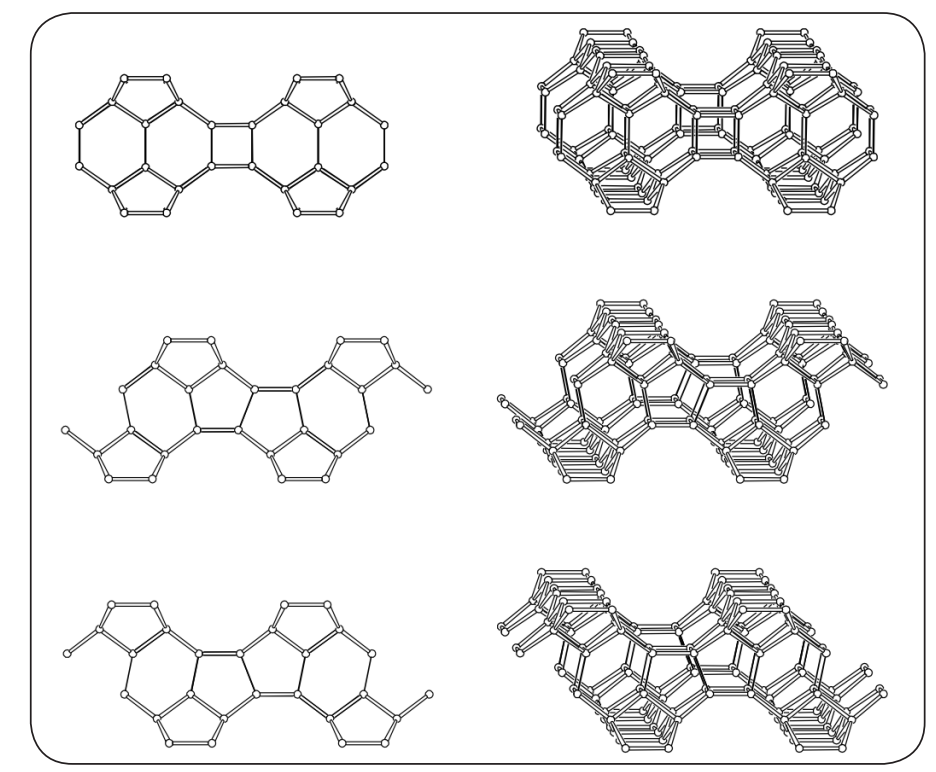

Figure 15. Schematic diagrams of the zeolite structure. Illustration www.iza-structure.org. "Catalog of Disorder in Zeolite Frameworks," H. Gies and H. van Koningsveld. Published on behalf of the Structure Commission of the International Zeolite Association. Copyright () 2000 International Zeolite Association.

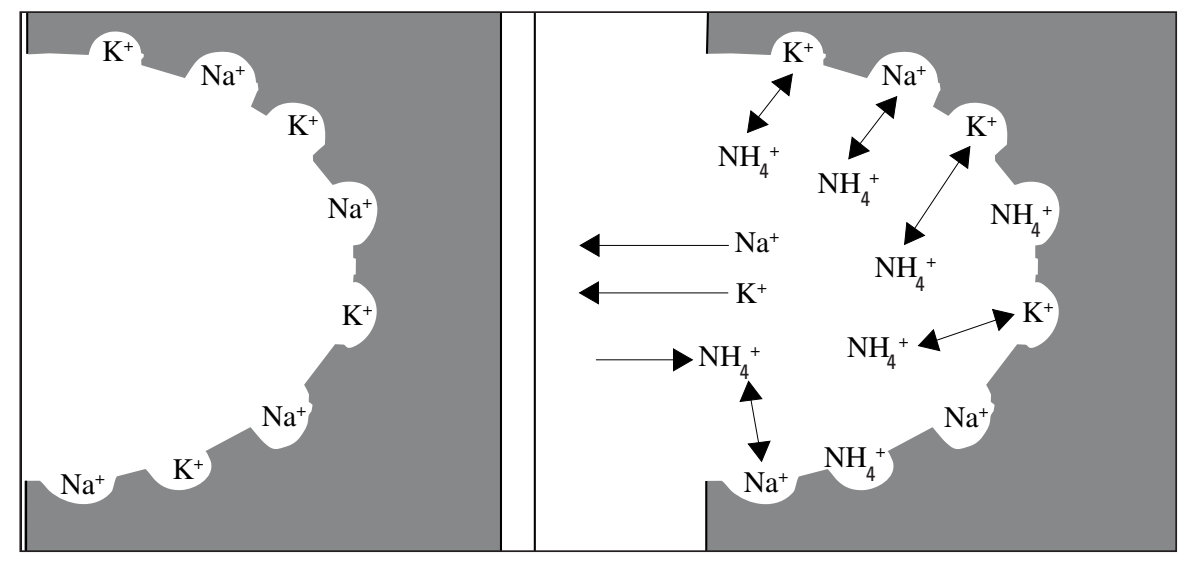

Figure 16. Zeolite ion exchange process. Fresh zeolite is pictured on the left. Sodium and potassium are ready to be exchanged with other ions. Right diagram illustrates release of $\mathrm{Na}^{+}$and $\mathrm{K}^{+}$in exchange for ammonium ions. Illustrations Jens Kallmeyer, GeoForschungsZentrum, Potsdam, Germany. 
ammonium) to $\mathrm{NO}_{3}$, thereby aerating, or oxygenating, the water system.

This excellent mineral has found its way into power generating plants. Power plants burn carbon-based (organic) fuels and emit air-polluting gases called VOCs (volatile organic compounds). To reduce these kinds of emissions, the stacks of some coal-fired power plants are lined with zeolite concentrators. Sulfur-containing waste gases are absorbed by the zeolite, thereby reducing the volume of sulfur oxides vented into the atmosphere. And, because zeolite is unaffected by the extreme heat of emission VOCs, it does not deteriorate over time (U.S. EPA, 1998).

Zeolite use in the automobile engine is even more ingenious. When gas engines are cold, they emit VOCs in their exhaust. Zeolite, in the engine's catalytic converter, adsorbs ${ }^{1}$ the cold engine emissions. As the engine warms up, the hot exhaust gases are desorbed from the zeolite and converted to an oxidized fuel. Thus, in a conventional combustion engine, zeolite prevents volatile gases from escape to the atmosphere and facilitates reuse of those very same VOCs. Amazing!

Another amazing zeolite application is its adaptation to the treatment of radioactive waste. Two radioactive elements, cesium (Cs) and strontium ( $\mathrm{Sr}$ ), accumulate in reactive wastewater. By introducing powdered zeolite to the wastewater, as much as $1 \mu \mathrm{g}$ (microgram (one millionth of a gram)) radioactive $\mathrm{Cs}$ and $\mathrm{Sr}$ per liter of water can be exchanged in the zeolite structure-a significant exchange rate (D.R. Liles, oral commun., 2005). When ion exchange reaches capacity, the zeolite is collected and mixed with concrete. The concrete is then cast as drums which can be disposed of in a landfill or in the oceans. Saltwater, either on land or in the sea, seems to have no disaggregating effect on the zeolite-concrete cast.

Certain zeolite minerals are routinely added to laundry detergents and water softeners. In laundry soaps, zeolite has replaced sodium tripolyphosphate, an environmentally harmful detergent additive. As a hard water treatment, zeolite reduces carbonate deposits in pipes by exchanging insoluble calcium and magnesium ions for potassium and sodium ions. The sodium and potassium ions are dissolved in the water while the calcium and magnesium are extracted and incorporated into the zeolite structure.

Zeolite has more uses than can be described in this format. Researchers in the fields of alternative energy, medicine, mining, agriculture, environmental safety, hygiene, and even pet care continue to discover practical uses for natural and synthetic zeolite. It is not surprising, given its unique structure and its ion exchange capacity, that zeolite has been called "The Magic Rock" (Mumpton, 1999).

\section{Borates}

In 1808 the element boron (B) was isolated by Joseph Gay-Lussac, a French chemist who documented its chemical

\footnotetext{
${ }^{1}$ Adsorb - the accumulation of gases, liquids, or solutes on the surface of a solid or liquid. Not to be confused with absorb, which means to take in by capillary, osmotic, solvent, or chemical action.
}

affinities and physical properties. Nine hundred years before Gay-Lussac characterized boron, a compound of the element was being used in ceramic glazes and by silversmiths in China and Arabia, respectively. The compound was called borax $\left(\mathrm{Na}_{2} \mathrm{~B}_{4} \mathrm{O}_{7} \cdot 10 \mathrm{H}_{2} \mathrm{O}\right.$, hydrated sodium borate). In 1881 a massive borate deposit was discovered in Death Valley, Nev. Two years later, the storied 20-mule teams were introduced to the desert valley to haul borax from mines to refineries (fig. 17).

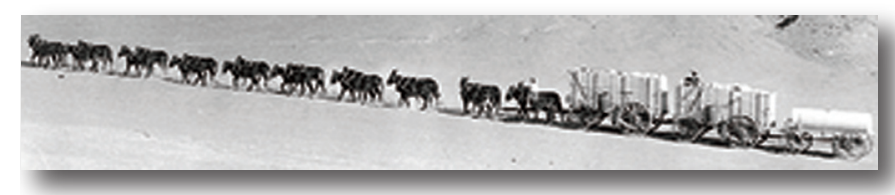

Figure 17. The legendary 20-mule team hauling borax in Death Valley, Nev., circa 1890. Photograph Santa Clarita Valley Historic Society/SCVHISTORY.com.

Unlike most elements, boron does not exist discretely in nature. It is always found in combination with other elements. Approximately 80 boron compounds have been identified worldwide. Only four boron minerals occur in the United States in abundance suitable for mining:

- Tincal (pronounced “tinkle," $\mathrm{Na}_{2} \mathbf{B}_{4} \mathrm{O}_{7} \cdot 10 \mathrm{H}_{2} \mathrm{O}$ )

- Kernite $\left(\mathrm{Na}_{2} \mathbf{B}_{4} \mathrm{O}_{7} \cdot 4 \mathrm{H}_{2} \mathrm{O}\right)$

- Ulexite (sometimes called "bunny tail," $\left.\mathrm{NaCaB}_{5} \mathrm{O}_{9} \cdot 8 \mathrm{H}_{2} \mathrm{O}\right)$

- Colemanite $\left(\mathrm{Ca}_{2} \mathrm{~B}_{6} \mathrm{O}_{11} \cdot 5 \mathrm{H}_{2} \mathrm{O}\right)$ (fig.18).

Laboratory studies indicate that these and other borates are about as toxic as table salt. The human body does not accumulate excess borates. Once ingested or inhaled, the body uses what is needed (less than $20 \mathrm{mg}$ per day) and expels the remainder. Additionally, borate minerals and the waste associated with borate mining are not regulated as irritants, toxins, carcinogens, or contaminants for any other organism or biotope.

Boron is an essential element in both natural and artificial systems. In nature, boron occurs in soils that formed from erosion of borate-bearing rocks. Its presence in a range of soils is ideal for most plant populations. As a micronutrient, boron contributes to plant reproductive and flowering cycles, pollen production, and energy distribution (fig. 19).

In the industrial world borates are used in the manufacture of insulation, fiberglass, and heat-resistant glass. About 43 percent of annual world borate production goes directly to the fiberglass and treated glass industries (IMA, 2003).

An incomplete list of other boron- or borate-containing products includes the following:

- Laundry detergents and other cleaning productsborates are an effective bleaching and stain removal agent.

- Paint, adhesives, and cosmetics — borates are added to these products for their buffering and dispersing 


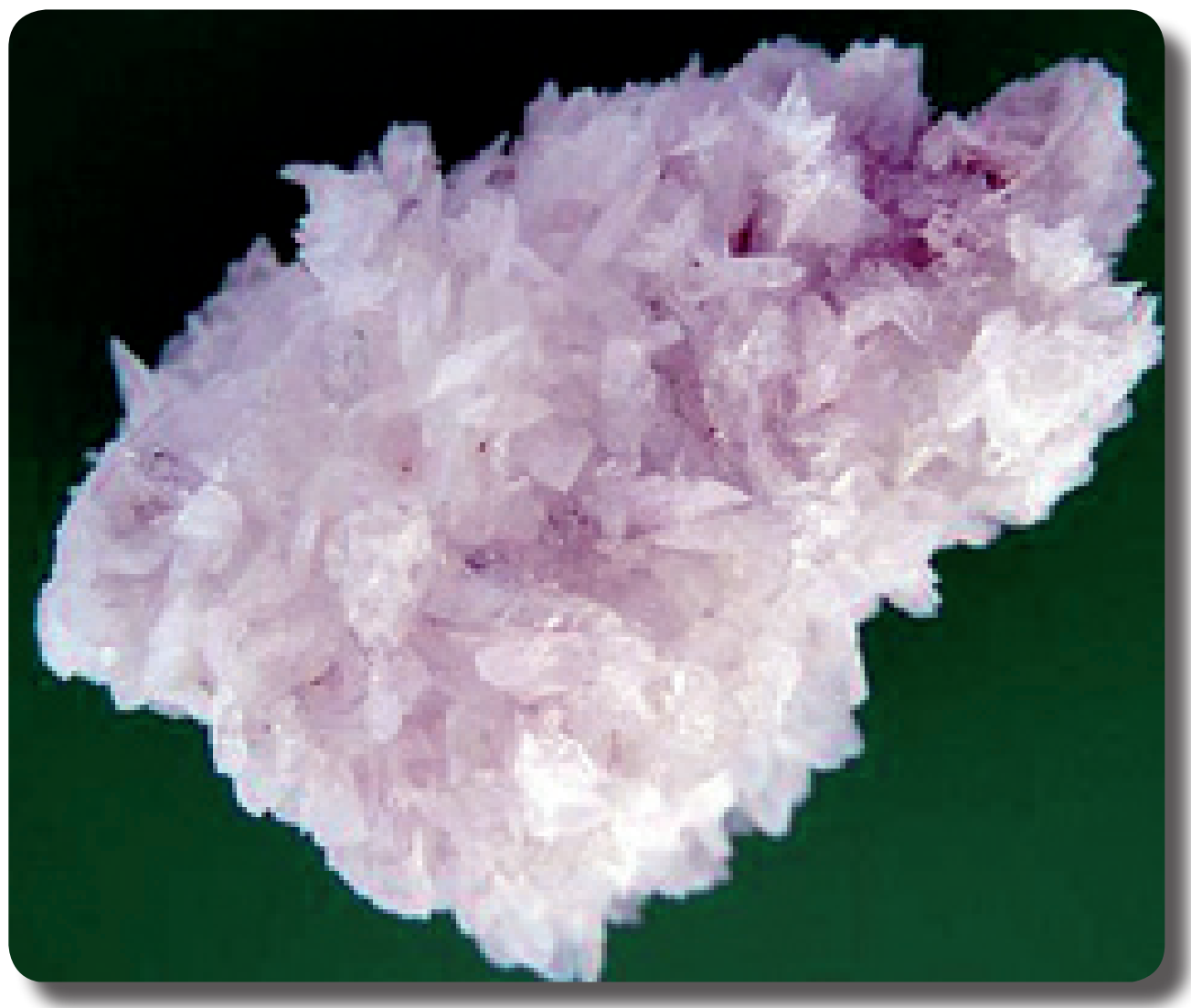

Figure 18. Colemanite crystals (dimensions and specimen locale unknown). Photograph Stonetrust, Inc., American Geological Institute image library. Image source Earth Science World Image Bank http://www.earthscienceworld.org/images.

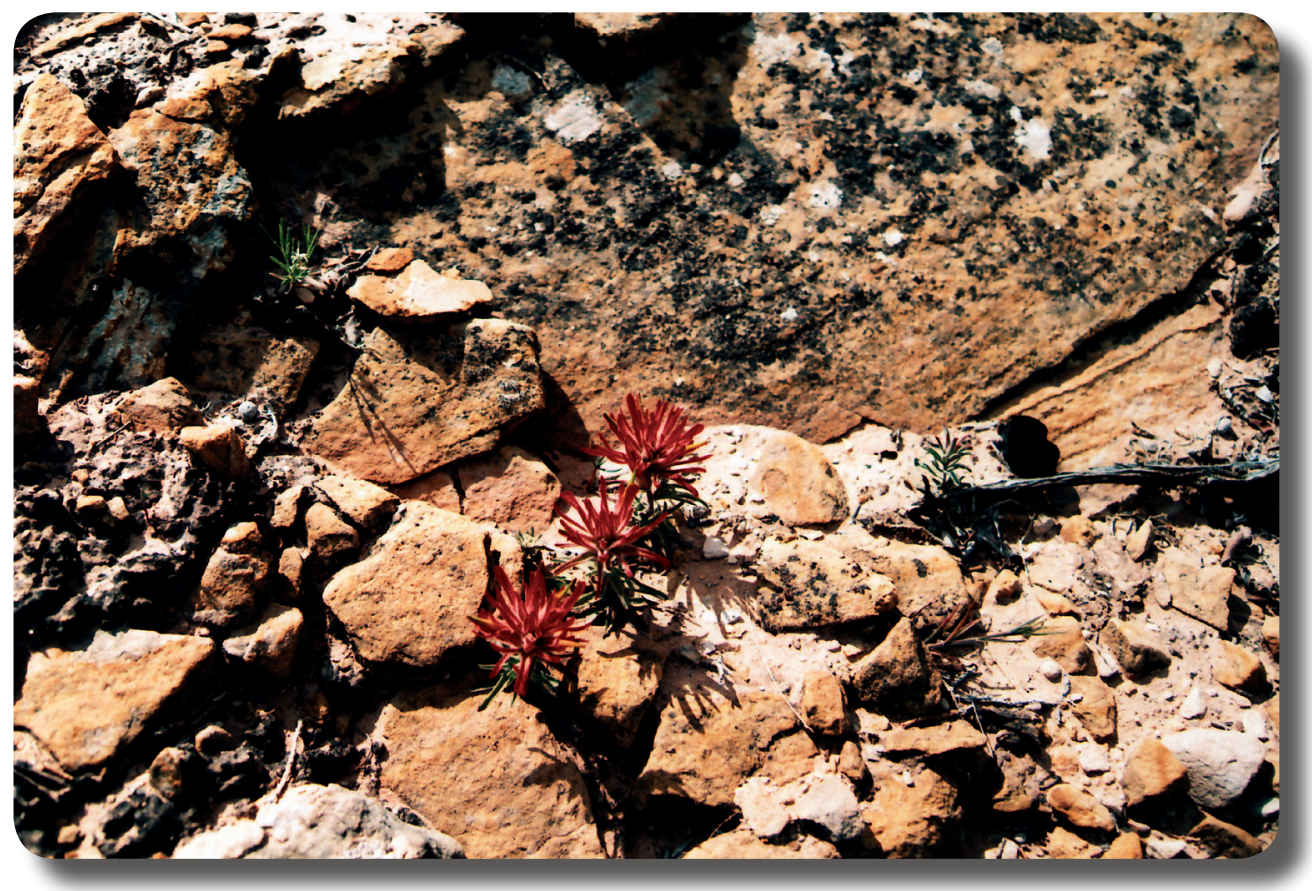

Figure 19. Bright-red Indian paintbrush in Death Valley, Nev., growing amid rocks high in borates-boron contributes to flowering cycles. Photograph by author. 
effect. Borate compounds have the measured capacity to balance acidity and alkalinity and to facilitate even distribution of disparate ingredients.

- Because boron can be adapted as an anti-corrosive, it is a primary ingredient in engine additives such as motor oil and antifreeze.

- Boron fibers, which have a very high tensile strength, have been added to plastics to make a material that is stronger than steel yet lighter than aluminum.

- When combined with zinc ( $\mathrm{Zn})$, borates can be applied as flame and smoke retardants.

And finally, because boron is able to absorb neutrons, its use has expanded to the field of atomic energy. It is used as a construction component of particle detectors and neutron shields and as an assimilation element in nuclear reactor rods.

\section{Gypsum}

Known to chemists as hydrous calcium sulfate $\left(\mathrm{CaSO}_{4} \cdot 2 \mathrm{H}_{2} \mathrm{O}\right)$, gypsum has a long history of use. Records dating to Greek antiquity describe a transparent mineral used to cover temple windows which cast a moon-like light on altars. The mineral was named "Selene" after the Greek moon goddess. The term continues to this day: the transparent form of gypsum is called selenite. Early Mediterranean texts refer to a rock called "gypsos," as do the cuneiform scripts of the ancient Assyrians. Modern archeology has identified gypsum as a wall dressing in Egyptian pyramids.

Gypsum is as important a mineral today as it was in the distant past. And it is mined and processed today much as it was by ancient Greeks and Semites. Mined or quarried, gypsum is heated at a relatively low temperature to remove water from its structure. This process is called calcination. The calcined gypsum is then ground to a fine powder known as gypsum stucco, or plaster of Paris. Water is reintroduced to the gypsum powder to produce a mortar that can be poured into any shaped mold and hardened. Gypsum is the only natural substance that can be calcined and then restored to its original rock-like state by the addition of water alone.

In the United States today, gypsum deposits are concentrated in two broad, lateral belts. One belt begins in southwest Texas and terminates about 1,450 miles away (2,300 kilometers) at the Niagara River in New York State. The other extends from California's Imperial Valley to northern Utah (fig. 20). The two gypsum belts supply 90 percent of the U.S. wallboard industry (Olson, 2004). Additionally, several million tons of gypsum is imported to the United States each year from Nova Scotia and Mexico.

Wallboard, or gypsum board, is one of the most important materials in the housing construction industry. The boards are formed by sandwiching a core of wet plaster between two sheets of paper board. When the core sets and dries, it becomes a strong, rigid, fire-resistant building material that can be cut to specific dimensions.

In recent years the construction materials industry has perfected a gypsum synthesis process that makes use of a byproduct of power generation. The sand-sized byproduct is collected from the coal desulfurization chambers of power plants. It is dewatered, recombined with other elements, rewetted, and then ground into a stucco and sold commercially. The synthetic product is chemically and physically comparable to natural gypsum.

Whether naturally occurring or synthesized, gypsum and its uses are not restricted to the wall-dressing industry. Gypsum is used as a sanitizing and whitening agent in toothpaste.

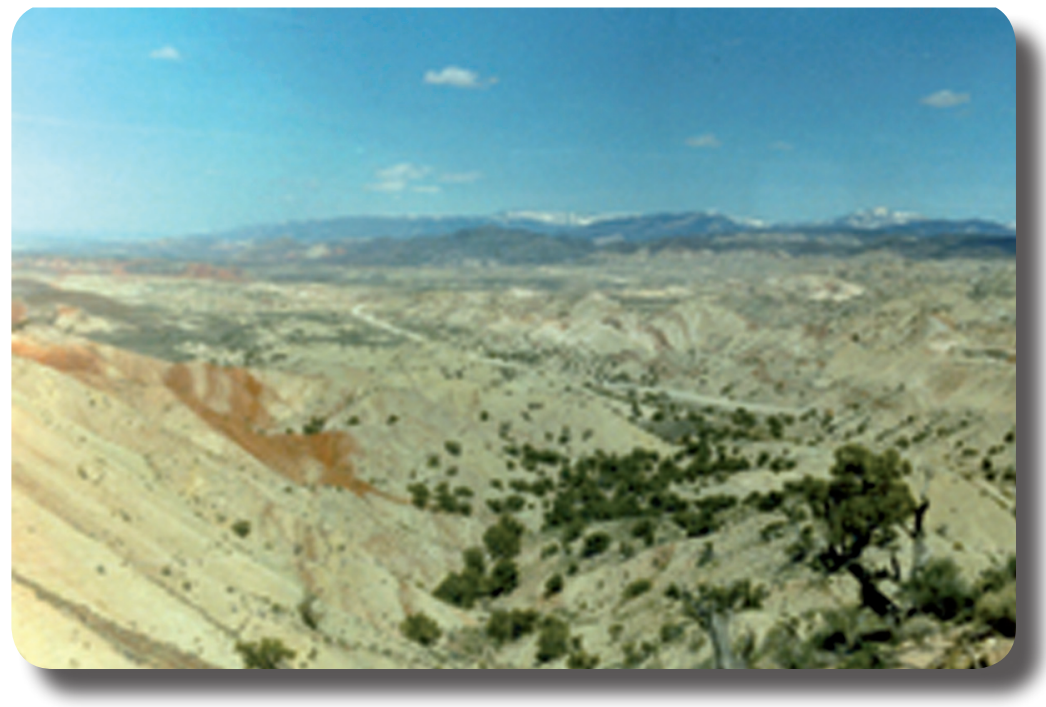

Figure 20. View looking north showing badland topography of the Jurassic Arapien Shale near Salina, Utah. Gypsum mines are in the center of the photograph (light mounds encircled by the road). Photograph by I.J. Witkind, 1982, USGS Photograph Library (image file wij097cp). 


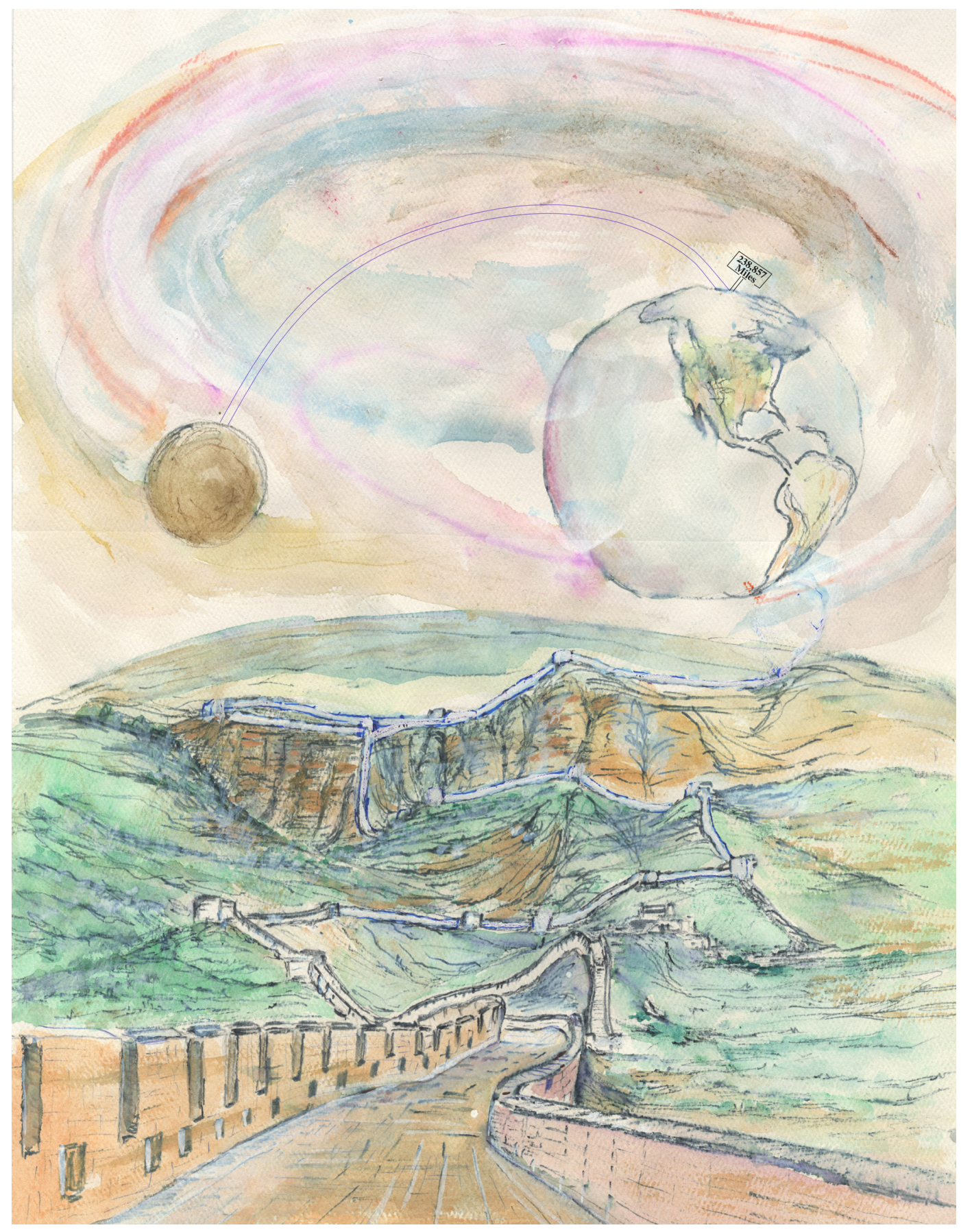

Figure 21. A gypsum promenade from the Earth to the Moon, and a gypsum wallboard wall on its way around the Earth. Original watercolor illustration by John Driscoll. 
It is formed into molds for electrical and mechanical fixtures, dental and medical prostheses, and even dinnerware. It is also applied to acidic soils as a neutralizing medium. These applications, however, account for a very small percentage of overall domestic annual use. The yearly production of wallboard used by the U.S. building construction industry is equal to a 16-ft wide pathway from the Earth to the Moon or a 275-ft wall encircling the entire Earth (fig. 21) or 36 billion square feet of material!

Despite this incredible consumption, gypsum deposits in the United States are just about limitless. Since the demand for housing and other buildings shows no signs of slacking, it is good to know that this particular industrial mineral is abundant and relatively inexpensive to extract and process.

\section{Industrial Sand}

When we think of sand we think of recreation on sundrenched beaches or vast stretches of shifting, shimmering dunes. Rarely do we equate sand with glassmaking, sophisticated electronics, or metallurgy. But glass products and some manufacturing processes are indeed dependent on industrial silica sand.

Most beaches around the world are accumulations of tiny, rounded fragments of such minerals as quartz, feldspar, hematite, hornblende, and magnetite. This mixture of mineral grains, while attractive to tourism promoters, is largely dismissed by economic geologists who characterize coastal beaches as impure sand deposits. Industrial sands, on the other hand, are high-purity quartz deposits requiring little in the way of processing to remove non-quartz grains.

Industrial sands are most commonly associated with inland geologic events involving massive uplift, erosion, and active winnowing in stream and lake beds. The natural winnowing, or separation process, occasionally produces ultraclean deposits of silicon dioxide grains $\left(\mathrm{SiO}_{2}\right)$, more commonly known as quartz.

Quartz is very hard, it is chemically inert, and it has a high melting point. In other words, it is a mineral that can withstand moderate impact, does not react with liquids, gases, or other solids, and can tolerate extreme temperatures. Quartz melts at approximately $1,600^{\circ} \mathrm{C}$, at which state, in combination with other minerals, it can be rolled or formed into flat, durable window glass, sterile containers for food and beverages, medical and scientific glassware, and television and computer monitor screens. The quality of these glass products is determined by the purity of the silica sand-the more pure the industrial sand, the better the color, clarity, and strength of the glass product made from it.

Like glassmakers, the ferrous and nonferrous foundry industries have also made impressive use of fine quartz sand. When combined with specific clay minerals (such as bentonite), industrial sand can be shaped into nearly any form from engine blocks to faucets. Because silica has an extremely high fusion point (the temperature at which a substance becomes molten), liquid metal alloys can be poured into silica-clay molds without inducing melt. Once the metal is removed from the mold, the sand-clay die can be recycled to make new molds.

Makers of paints and coatings add high-purity silica to their products to improve tint retention, color consistency, and weathering resistance.

The construction supply industry in partnership with industrial chemists has developed stuccos, epoxy compounds, and asphalt mixtures that contain prescribed amounts of industrial sand. This newest generation of construction materials promises extended coverage and durability.

For decades, the fossil fuel industry has made specialized use of silica sand. The pumping of pure, well-rounded sand into deep wells causes rock fissures and fractures to stay propped open, thereby increasing the flow rate of natural gas and oil. The structural strength and inherent corrosion resistance of silica sand guarantee its integrity to depths of $8,000 \mathrm{ft}$ or more.

In compound form, silica sand contributes to the production of quality glass, cast metal essentials like machine tools and stoves, and long-lasting construction materials. But its utility becomes nothing short of astounding when the $\mathrm{SiO}_{2}$ molecule is deconstructed. Using an arc furnace fueled by coke (degassed coal), silicon can be separated from oxygen. In its reduced form silicon metal is used in the production of other beneficial chemical compounds. Examples include silicon tetrachloride $\left(\mathrm{SiCl}_{4}\right)$, a component of semiconductors and optic fibers; and water-soluble amorphous sodium silicate $\left(\mathrm{Na}_{2} \mathrm{O} \cdot x \mathrm{SiO}_{2}\right)$, an egg preservative. (Eggs are dipped in an aqueous sodium silicate solution; when dry, the solution forms a bacteria barrier around the eggshell, preserving the freshness of the egg for months.)

Just as silicon can be separated from oxygen, it can also be chemically synthesized, or cultured, for use in the electronics industry (fig. 22). Advanced microcircuits, frequency controls, and timers all require integrated silicon grains, nearly all of which are manmade.

Clearly, industrial sand (known in industry as silica sand or high-purity quartz) is a crucial element of everyday life. It is present in our double-pane windows and our glossy paints. It facilitates medical research and voice and image transmission. And, believe it or not, it is even lurking in those sinister bunkers on the golf course (fig. 23).

\section{Talc}

Talc is a very soft mineral, the softest on the Mohs scale. ${ }^{2}$ Talc varies in color from pale green to yellowish white

${ }^{2}$ The Mohs scale is a mineral identification system based on comparative hardness. The scale lists 10 minerals in order from 1-softest (talc) to 10-hardest (diamond). The system was developed by Friedrich Mohs, an 18th century German mineralogist. 


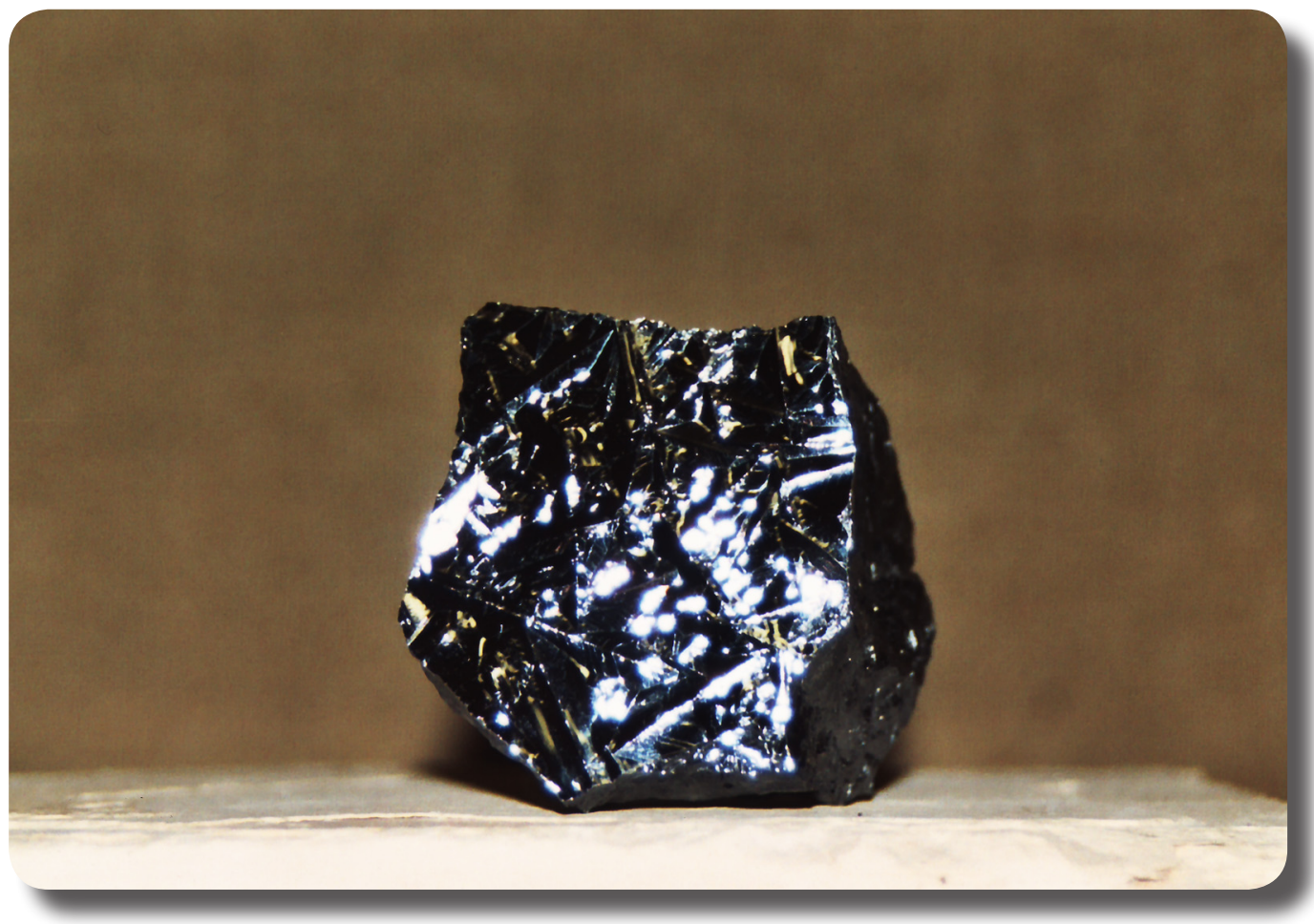

Figure 22. Synthetic silicon crystal measuring $3 \times 3 \times 3$ in. Photograph by author.

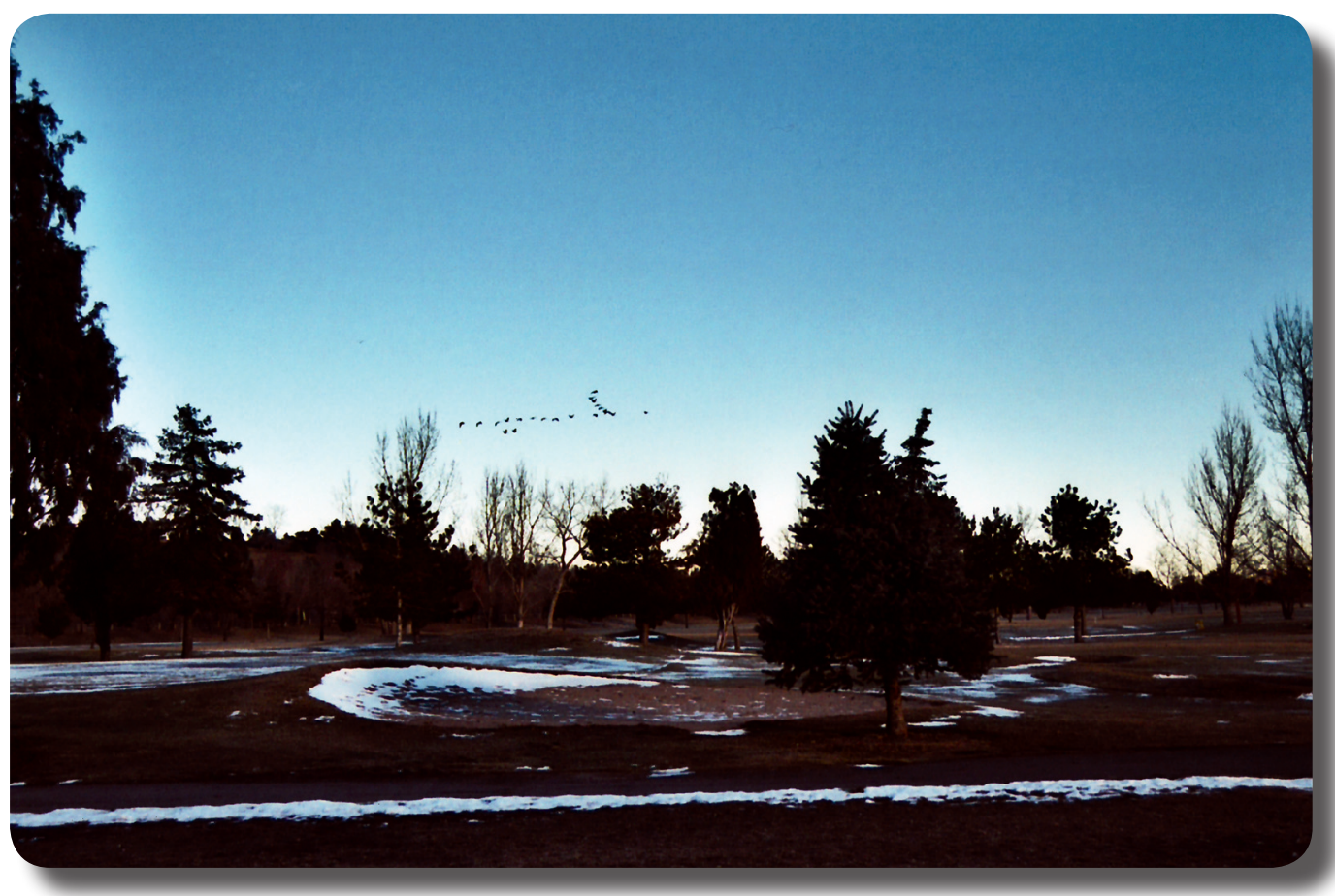

Figure 23. A snow-rimmed sand bunker, public golf course. Photograph by author. 
to bright white. It is generally flaky or scaly in appearance and always slippery to the touch. Referred to by chemists as hydrous magnesium silicate, talc has the chemical formula $\mathrm{Mg}_{3} \mathrm{Si}_{4} \mathrm{O}_{10}(\mathrm{OH})_{2}$. In pure form, talc is 63.5 percent $\mathrm{SiO}_{2}$ (silicon dioxide), 31.7 percent $\mathrm{MgO}$ (magnesium oxide), and about 5 percent water. Talc rarely occurs in pure form in nature. It is most often intergrown with chlorite, epidote, diopside, and (or) tremolite. Mine operators and end-users describe talc as one or the other of the following:

- Steatite - a fine-grained, massive, compact form

- Soft, platy - considered the most commercial form of talc; at least 90 percent of the world's talc deposits are of the soft and flaky variety

- Tremolite talc_-usually occurring as a massive or laminated (thin layers) rock consisting of intergrowths of tremolite $\left(\mathrm{Ca}_{2} \mathrm{Mg}_{5} \mathrm{Si}_{8} \mathrm{O}_{22}(\mathrm{OH})_{2}\right)$ and talc and the accessory minerals anthophyllite $\left((\mathrm{Mg}, \mathrm{Fe})_{7} \mathrm{Si}_{8} \mathrm{O}_{22}(\mathrm{OH})_{2}\right)$, calcite $\left(\mathrm{CaCO}_{3}\right)$, and dolomite $\left(\mathrm{CaMg}\left(\mathrm{CO}_{3}\right)_{2}\right)$

- Mixed talc - any type of talc that is of moderate to low purity and (or) growing in combination with oxide minerals such as hematite and magnetite. Mixed talc is commonly known as "soapstone."

Large active talc mines are located in Montana (the largest producer), Texas, Vermont, and upstate New York (tremolitic talc). The former two deposits are characterized as dense microcrystalline ores, meaning individual talc crystals are only visible with the aid of a microscope. Macro, or mega, crystals - those which are visible to the unaided eye-are mined in northern Vermont and upstate New York. In general, the macrocrystalline talcs contain a higher percentage of impurities than the microcrystalline species and require froth flotation refinement. Froth flotation is a process used to separate the desired mineral (talc) from gangue, or waste rock (tremolite or dolomite, for example). First, the ore is crushed into a fine powder and then conveyed to a bulk liquid containing an organic surfactant. The surfactant, similar to a detergent, reduces the surface tension of the liquid and enables upward movement, or flotation, of talc grains. As grains accumulate at the surface of the bulk liquid, they are scraped into a clean, aerated water bath. There, the fine talc grains attach to air bubbles and rise in columns to form a froth on the bath surface. The froth is pumped off and analyzed for purity.

In addition to being size-specific, industrial applications are also type-specific. For example, the very finest talcs, produced by advanced milling technology, are essential to the polypropylene (light, conformable plastic) industry-makers of automotive dashboards and bumpers. The stiffness and stability of these molded components are due in large part to a thermoplastic recipe that includes exceptionally clean microcrystalline talc.

The coatings industry is another major consumer of the fine, platy variety of talc. Marine and automotive primers and topcoats, traffic paints, powder coatings, crack fillers, and caulks consume about 180,000 short tons of soft talc each year (Ciullo and Robinson, 2003). Adding platy talc to coating compounds markedly improves dispersion and brushability, as well as crack, rupture, and corrosion resistance. Microcrystalline talc is structured like the scales of a fish-aligned and overlapping_forming a nearly impenetrable barrier to humidity or water, the common causes of coating "blisters," cracks, and discoloration (fig. 24).

Tremolitic talcs also have their place in coating manufacturing. Coarser than platy talcs, tremolite talcs offer greater scrub resistance and increased light-scatter for a high gloss finish. In addition to its utility in paints and surface coatings, tremolite talc is a mineral component of floor and wall tiles, sanitary ware, and ceramic glazes.

In the paper industry mixed talc is used to extract resinous particles from pulps and residue ink from recycled paper. High-speed printing processes rely on paper that has been treated with low-purity talc to eliminate surface friction.

Natural steatite, because it occurs as massive bodies, is often quarried for the production of statuary and other carved objects. Aside from its esthetic value, this fine-grained talc is used by the electronics and pharmaceutical industries. The former has developed a steatite-alumina compound that can be pressed into cellular phone components, thermostats, and semiconductor devices. Drug makers use only pure-grade steatite as a pill additive and preservative.

And finally, bubble blowers everywhere must appreciate talc for the nonstick nature of gum, and fashion-conscious women (and men) for the sheen and transparency of cosmetics.

\section{Stone Products-Aggregate, Dimension Stone, and Abrasives}

An essential and frequently overlooked industrial mineral is known collectively as coarse or natural aggregate. Coarse aggregate is generally described as nonmetallic, nonfuel rock fragments, which include gravel, crushed stone, and sand (fig. $25)$. Gravel is defined as naturally occurring rounded rock particles of a size ranging from $3 /{ }_{16}$ in. to 3 in. Crushed stone is a manufactured product usually obtained by the crushing of bedrock, boulders, cobbles, or gravel. Sand is smaller than gravel, but larger than silt and clay.

So, why would unassuming rock fragments rank as one of the most important industrial minerals? The answer is that aggregate is the literal foundation of our homes and offices, roadways and runways, bridges, dams, and rail lines (fig. 26). This unspectacular material is the fundamental component of water and sewage filtration systems. It is used to reshape, rehabilitate, and conserve landscapes. Without aggregate there would be no high-speed transportation networks, no on-demand clean tap water, no reclaimed open spaces or urban walking trails, and no convenient buildings in which to work, play, learn, or sleep. 

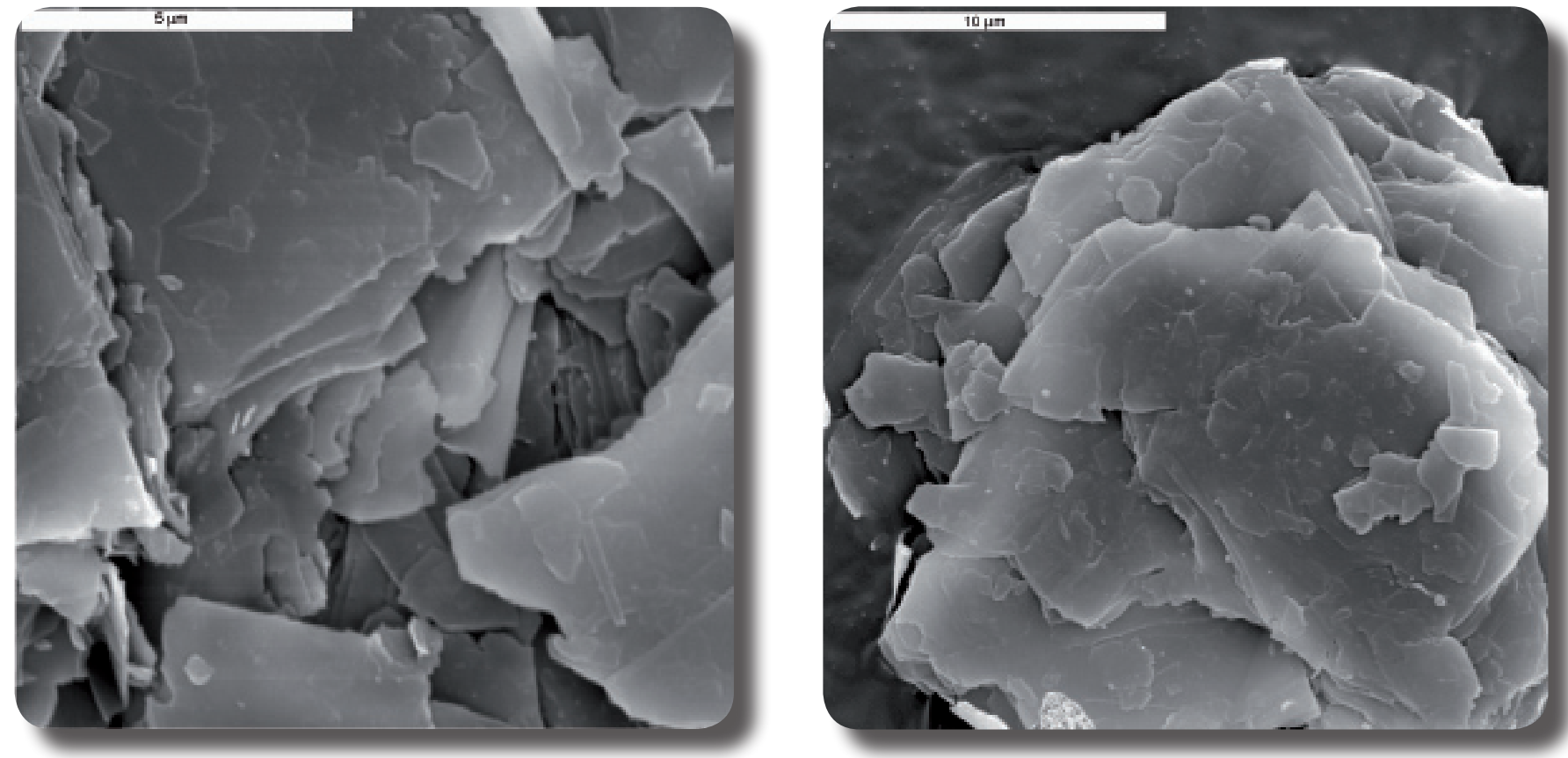

Figure 24. Scanning electron microscope (SEM) images of microcrystalline talc crystals. Courtesy of B.S. Van Gosen.

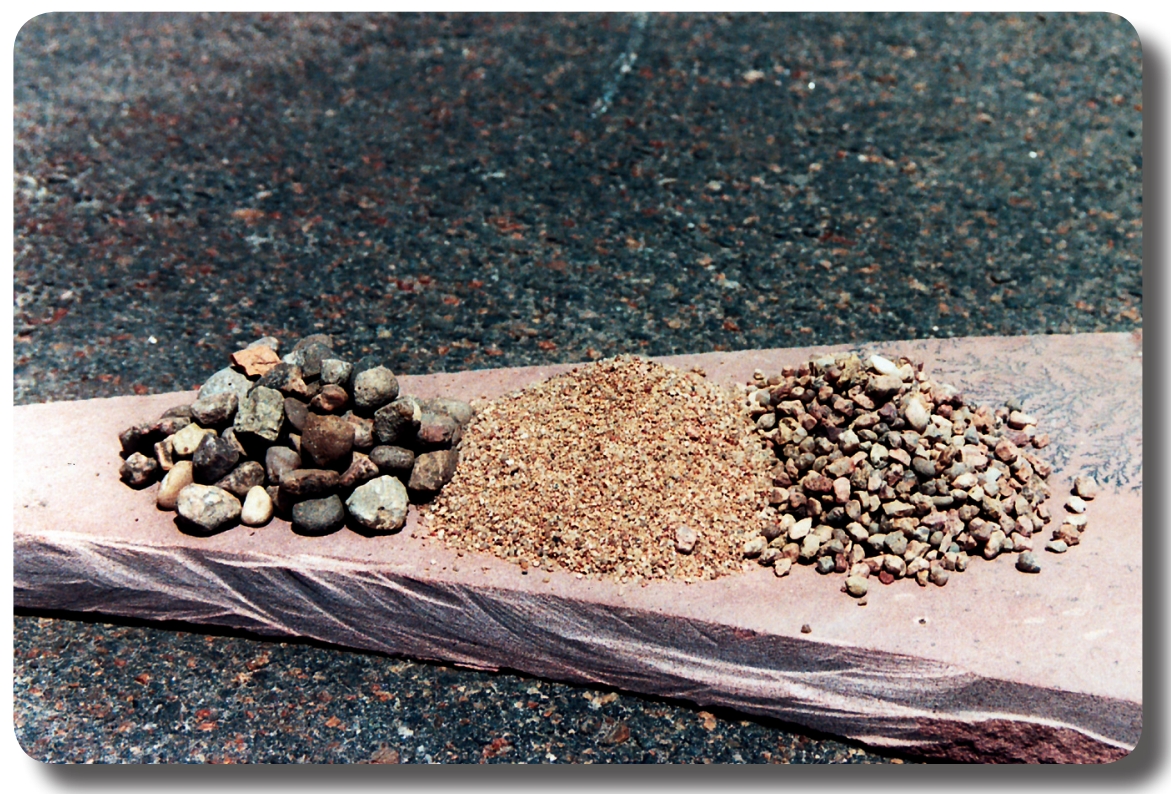

Figure 25. Pebbles, coarse sand, and gravel (left to right). Red sandstone slab measures 24 in. long. Photograph by author. 

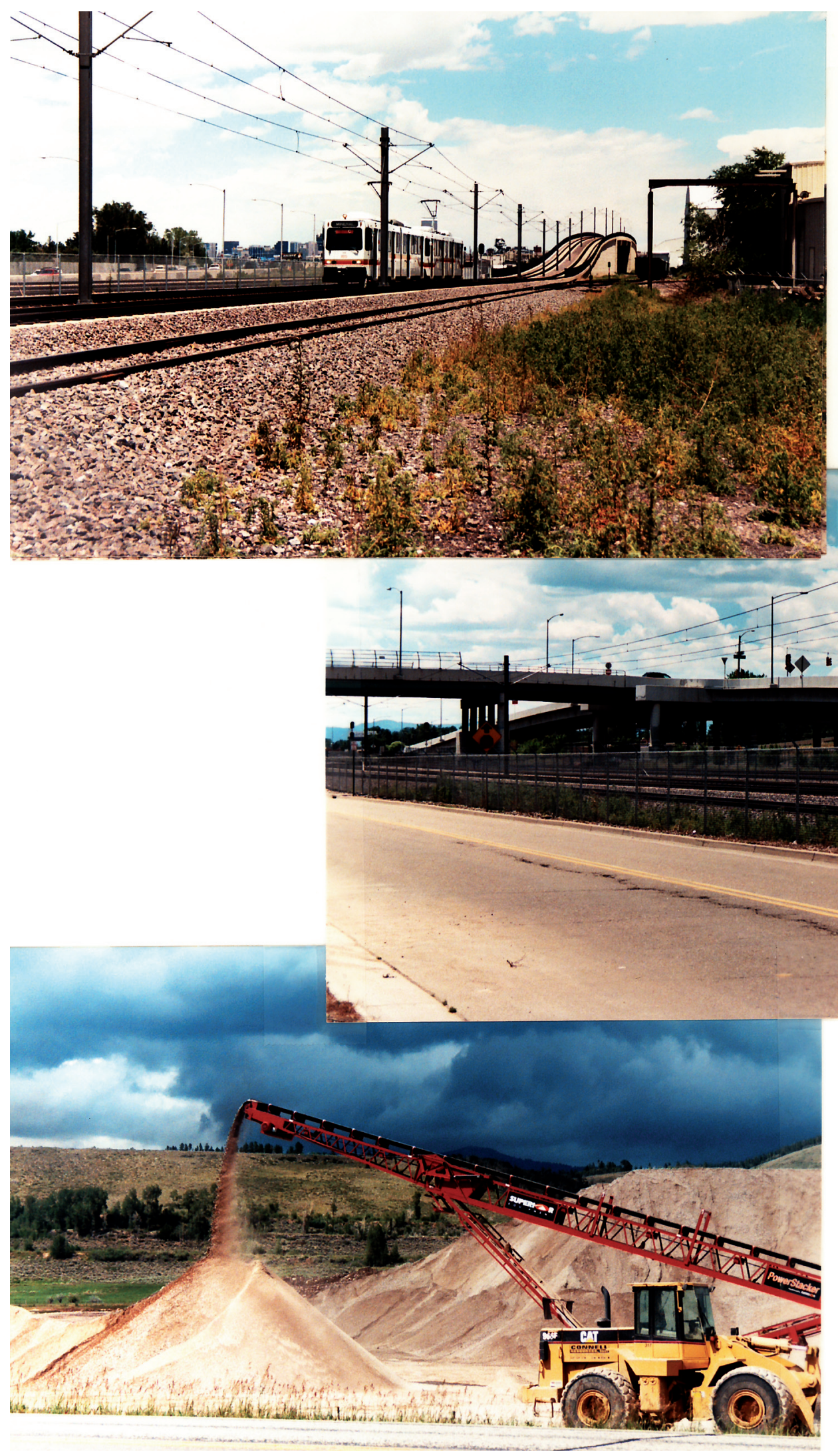

Figure 26. Uses and production of aggregate. Top, train rails with crushed stone substructure. Middle, heavily trafficked concrete overpass. Bottom, aggregate mining and processing near Saratoga, Wyo. Photographs by author. 


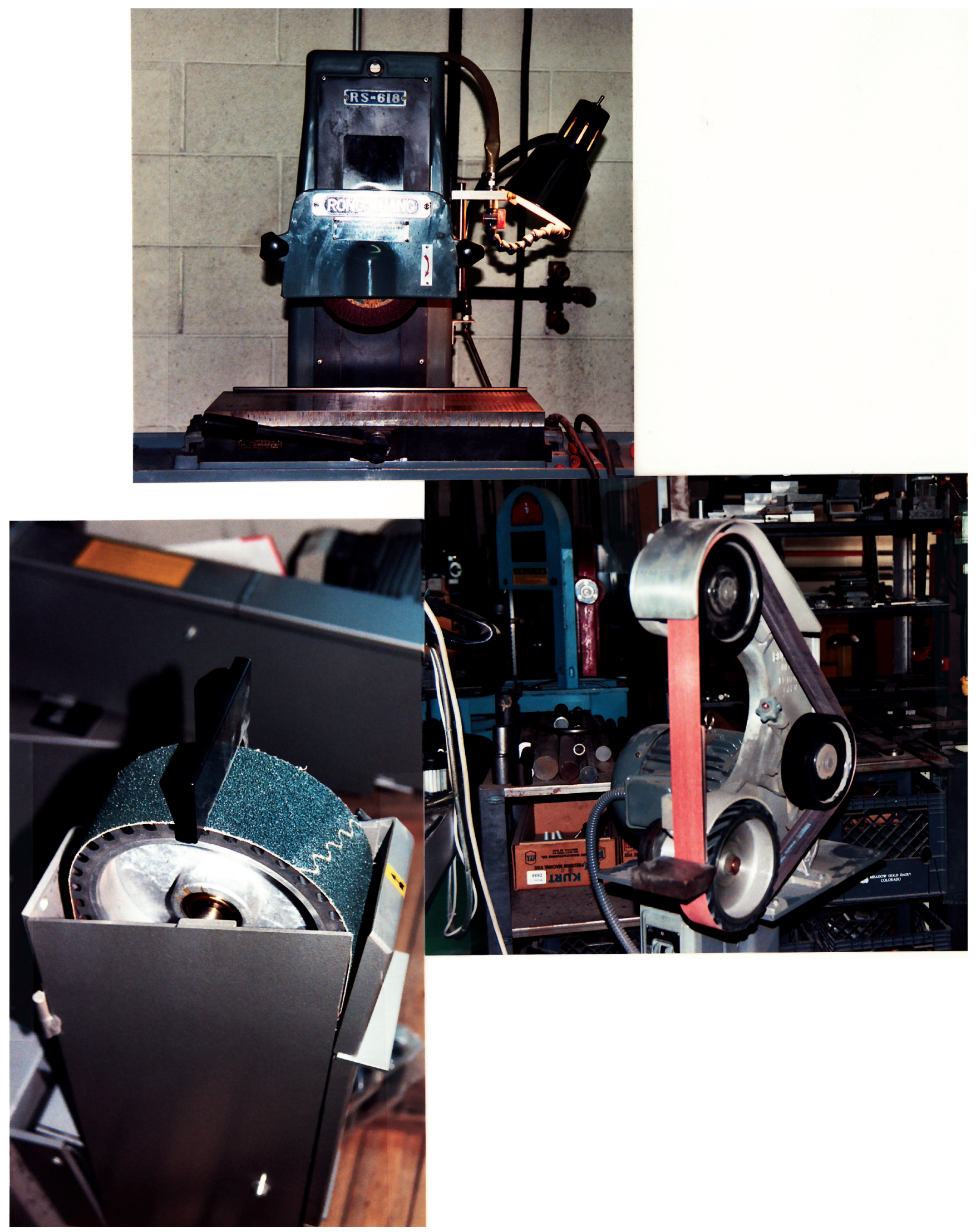

Figure 27. Uses of aggregate abrasive. Top, horizontal grinder with replaceable abrasive wheel. Middle, belt sander. Bottom, very coarse sanding strip. Photographs by author. 
Aggregate, like other industrial minerals, is mined or quarried. First, a sizable deposit of strong, weather-resistant aggregate is located, then mining permits are approved by local, State, or Federal government authorities, and finally, drilling, blasting, loading, crushing, and screening commence at the deposit site. From the mine, specific sized aggregate is hauled by truck, train, or barge to a road construction project where it is spread as the stabilizing under-layer of a paved highway or residential street; to a concrete plant where it is mixed with cement and subsequently poured as surface pavement or a building foundation; to a municipal water treatment plant to be incorporated in a through-flow filtering system; to a retaining structure or airport runway needing repair; to a bridge reinforcement or erosion control project; or to a redevelopment site where it is layered on by the ton. The vitality of commerce, cities, and neighborhoods depends on natural coarse aggregate.

Not all natural stone products are aggregates. A special type of stone called dimension stone is sometimes quarried for decorative use. Slabs of granite, dolomite, marble, and slate are the preferred rock for exterior and interior wall dressings, countertops, and floors. In its unfinished state dimension stone is interesting and attractive. But its real beauty is apparent only after it has been polished-tiny fossilized creatures or distinctive minerals are revealed in the matrix of the stone.

To obtain a polished finish, another type of stone, known as abrasives, is employed. Abrasive aggregates are extremely hard, fine mineral particles. They include iron oxides and corundum, industrial garnets and diamonds. These abrasive minerals are bonded to cutters and grinders, or imbedded in cloth or heavy paper (fig. 27). Every commercial and amateur fabricator and refurbisher who produces a clean cut or fine smooth finish owes his or her handiwork to industrial aggregate of the abrasive kind.

There can be no doubt that use of aggregate and other stone products contributes to affluence and comfort. Paved roads and reliable rail lines make possible a constant supply of fuel and food. Dirt roads, by contrast, can be punishing and unpredictable. A filtered municipal water supply guarantees potability. Unfiltered, untreated water assures microbial disease. Acts of nature can level a village built of wood, but stone buildings can withstand fire and flood.

Imagine for a moment the terraced, irrigated slopes of the ancient Ecuadoran Imaru people, ${ }^{3}$ or the precise roads and aqueducts of early Rome. Imagine also the castle fortresses of the Celtic Golden Age and the engineered harbor of long-ago Alexandria-people and places as different as copper and coconuts, yet the same in one respect: their practical use of stone, the natural resource that fostered social stability, political continuity, assimilation, and economic expansion. Many of

\footnotetext{
${ }^{3}$ The Andes Mountains (Imaru highlands) trend north-south through the center of Ecuador.
}

the standing stone structures built by these and other venerable peoples remind us that aggregate is the industrial mineral that has had the greatest effect on history: the one material that since ancient time has separated the primitive from the progressive.

So, the next time you see a pile of nondescript rocks, think about snug dwellings, safe landings, and the roads you travel.

\section{Final Words}

Driving west on Interstate 70 over the Colorado Rockies, motorists are reminded of the mining history of the region - those heady days of gold and silver that beckoned the adventurer. Long-ago laughter and piano music, gun shots and galloping hooves can be heard on the mountain wind now and then. Those were the good old days of hard rock, hard labor, and hard drinking. There wasn't anything soft in the life of a 19 th century miner. The roads in town or up the mountain had two seasons-dust or mud. Parasites lived in the water supply necessitating boiling beforehand. Clothes were laundered in caustic lye. A scarcity of toothpaste meant rotten teeth. Communication was a hard ride on a hard road. Neither cardboard nor oil cloth kept the wind or wet or cold from the chinked cabin interior. Commodes were a brass pot or a hole in the ground. Pain relievers were sold without a guarantee of purity. The air in camp was grimy with wood smoke or coal dust. And food production was only as good as the soil or the fodder that sustained it. Though few prospectors found the motherlode, many would have found consolation in clean water, window glass, fiber insulation, and guaranteed pain remedies. The real hardships of the 19th century prospector's life are all but forgotten in many parts of the 21 st century world - a world of shatterproof glass, long-lasting pavement, purified water, and emission scrubbers; a world made comfortable and predictable by amazing industrial minerals.

\section{Selected References}

About..., accessed July 6, 2004 at URL http://www.chemistry. about.com.

ASTM International, 2004, C494/C494M-04 Standard specification for chemical admixtures for concrete: Accessed March 12, 2004 at URL http://www.cement.org.

Ciullo, P.A., and Robinson, S., 2003, Talc-Shape and form meet function: Accessed May 22, 2004 at URL http://www.pcimag.com. 
Davis, W.S., 1912, Readings in ancient history-Illustrative extracts from the sources, Two Volumes: Boston, Mass., Allyn and Bacon, Volume II, Rome and the West, p. 215-222.

Dexter, A.R., 1998, Advances in characterization of soil structures: Soils and Tillage Research, p. 199-238.

Goldman, H.B., 1994, Sand and gravel, in Carr, D.D., ed., Industrial minerals and rocks, Sixth Edition: Society for Mining, Metallurgy, and Exploration, Inc., p. 869-877.

Houk, C.C., and Post, R., 1996, Chemistry-Concepts and problems-A self-teaching guide: New York, John Wiley, $384 \mathrm{p}$.

IMA (Industrial Minerals Association)-North America, 2003, Borates: Accessed February 12, 2004 at URL http:// www.ima-na.org.

Knepper, D.H., ed., 2002, Planning for the conservation and development of infrastructure resources in urban areasColorado Front Range Urban Corridor: U.S. Geological Survey Circular 1219, 32 p.

Langer, W.H., 1988, Natural aggregates of the conterminous United States: U.S. Geological Survey Bulletin 1594, 33 p.

Mumpton, F.A., ed., 1981, Special zeolite issue: Clays and Clay Minerals, v. 29, no. 5, 212 p.

Mumpton, F.A., 1999, La Roca Magica-Uses of natural zeolites in agriculture and Industry: Proceedings of the National Academy of Sciences, v. 96, p. 3465-3470.

Murphy, J.A., 1997, Geology tour of Denver's Capitol Hill stone buildings: Historic Denver, Inc., 96 p.

NAWC (North American Weather Consultants, Inc.), 2003, Cloud seeding-Weather modification: Accessed December 10, 2003 at URL http://nawc@nawcinc.com.

Noe, D.C., 1997, A guide to swelling soils for Colorado homebuyers and homeowners: Colorado Geological Survey Special Publication, 76 p.

Olson, D.W., 2004, Gypsum: U.S. Geological Survey Mineral Commodity Summaries 2004, p. 76.

Portland Cement Association, 2004, Accessed March 15, 2004 at URL http://www.cement.org.

Shacklette, H.T., and Boerngen, J.G., 1984, Element concentrations in soils and other surficial materials of the conterminous United States: U.S. Geological Survey Professional Paper 1270, 105 p.
Sharp, R.P., and Glazner, A.F., 1997, Geology underfoot in Death Valley and Owens Valley: Missoula, Mont., Mountain Press Publishing Company, 319 p.

Smallwood, C.L., Lipscomb, J., Swartout, J., and Tueschler, L., 2004, Toxicological review of boron and compounds: U.S. Environmental Protection Agency IRIS 7440-42-8, $134 \mathrm{p}$.

Swarm, L., and Fitzgerald, S., 1992, Use and application of salt in aquaculture: North Central Regional Aquaculture Center, Publication 105, 2 p.

Tepordei, V.V., 1997, Natural aggregates-Foundation of America's future: U.S. Geological Survey Fact Sheet FS-144-97, 4 p.

U.S. Department of Agriculture, 1969, Handbook No. 60-Diagnosis and improvement of saline and alkali soils: U.S. Department of Agriculture Special Publication, available on the Web at http://www.ussl.ars.usda.gov.

U.S. Environmental Protection Agency, 1995, EPA Office of Compliance Sector Notebook Project-Profile of the nonfuel, non-metal mining industry: EPA 310-R-95-011, 6 p.

U.S. EPA (Environmental Protection Agency), 1998, Zeolite-A versatile air pollutant adsorber: EPA Technical Bulletin 456/F-98-004, p. 7.

U.S. Geological Survey, 1998, Front Range Infrastructure Resources Project-Aggregate resources activities: U.S. Geological Survey Fact Sheet FS-119-98, 4 p.

U.S. Geological Survey, 2000, Nitrogen in the Mississippi Basin-Estimating sources and predicting flux to the Gulf of Mexico: U.S. Geological Survey Fact Sheet FS-135-00, $2 \mathrm{p}$.

U.S. Geological Survey, 2000, U.S. talc-Baby powder and much more: U.S. Geological Survey Fact Sheet FS-0065-00, $2 \mathrm{p}$.

U.S. Geological Survey, 2004, Mineral commodity summaries, 2004: Accessed July 7, 2004 at URL http://minerals.er.usgs. gov/minerals/pubs/mcs/2004.

van Oss, H.G., 2004, Cement: U.S. Geological Survey Mineral Commodity Summaries 2004, p. 42. 


\section{Appendix. Domestic and World Production of Industrial Minerals}

\begin{tabular}{|c|c|c|c|c|c|c|c|c|}
\hline \multirow[t]{2}{*}{$\begin{array}{c}\text { Industrial } \\
\text { mineral }\end{array}$} & \multicolumn{2}{|c|}{$\begin{array}{c}\text { Domestic production } \\
\text { in thousand or million } \\
\text { metric tons } \\
\text { (t, thousand; } m \text {, million) }\end{array}$} & \multirow{2}{*}{$\begin{array}{c}\begin{array}{c}\text { Domestic active } \\
\text { quarries, pits, } \\
\text { mines }\end{array} \\
2003\end{array}$} & \multicolumn{2}{|c|}{$\begin{array}{l}\text { Average price } \\
\begin{array}{l}\text { U.S. dollars per metric } \\
\text { ton }\end{array}\end{array}$} & \multicolumn{2}{|c|}{ Employment } & \multirow{2}{*}{$\begin{array}{c}\text { Total value } \\
\text { (raw) } \\
\text { U.S. dollars } \\
2003\end{array}$} \\
\hline & 2002 & 2003 & & 2002 & 2003 & 2002 & 2003 & \\
\hline Bentonite & $3,970(\mathrm{t})$ & $3,970(\mathrm{t})$ & $760(p)$ & 45 & 45 & 6,550 & 6,400 & $\$ 1.6$ billion \\
\hline Borates & $518(\mathrm{t})$ & $536(t)$ & $4(p)$ & 359 & $\begin{array}{c}\text { Not } \\
\text { available }\end{array}$ & 1,300 & 1,300 & 275 million \\
\hline $\begin{array}{l}\text { Crushed } \\
\text { stone }\end{array}$ & $\begin{array}{l}1,520 \\
(\mathrm{~m})\end{array}$ & $1,490(\mathrm{~m})$ & $3,330(q)$ & 5.71 & 5.78 & 79,000 & 78,000 & 8.6 billion \\
\hline $\begin{array}{l}\text { Dimension } \\
\text { stone }\end{array}$ & $1,260(\mathrm{t})$ & $1,350(\mathrm{t})$ & $176(q)$ & $\begin{array}{l}\text { Variable. } \\
\text { Depends } \\
\text { on type of } \\
\text { product }\end{array}$ & $\begin{array}{c}\text { Variable. } \\
\text { Depends } \\
\text { on type of } \\
\text { product }\end{array}$ & 1,500 & 1,500 & 236 million \\
\hline $\begin{array}{l}\text { Sand and } \\
\text { gravel }\end{array}$ & $\begin{array}{c}1,130 \\
(\mathrm{~m})\end{array}$ & $1,130(\mathrm{~m})$ & $6,400(q, p)$ & 5.07 & 5.14 & 35,300 & 35,300 & 5.8 billion \\
\hline $\begin{array}{c}\text { Gypsum } \\
\text { (crude) }\end{array}$ & $\begin{array}{l}15,700 \\
(\mathrm{~m})\end{array}$ & $16,000(\mathrm{~m})$ & $50(\mathrm{~m})$ & 6.9 & 6.9 & 5,900 & 5,900 & 111 million \\
\hline Industrial sand & $\begin{array}{c}\text { Domestic } \\
\text { mining and } \\
\text { processing } \\
\text { ended in } \\
1997\end{array}$ & $\begin{array}{c}\text { Not } \\
\text { applicable }\end{array}$ & $\begin{array}{l}\text { U.S. 100\% } \\
\text { import reliant }\end{array}$ & $\begin{array}{l}\text { Variable. } \\
\text { Depends on } \\
\text { country of } \\
\text { origin }\end{array}$ & $\begin{array}{l}\text { Variable. } \\
\text { Depends on } \\
\text { country of } \\
\text { origin }\end{array}$ & $\begin{array}{l}\text { Employment } \\
\text { figures } \\
\text { unavailable }\end{array}$ & $\begin{array}{c}\text { Employment } \\
\text { figures } \\
\text { unavailable }\end{array}$ & $\begin{array}{l}\text { Total value } \\
\text { unavailable for } \\
2003\end{array}$ \\
\hline $\begin{array}{l}\text { Refined } \\
\text { silicon }\end{array}$ & $261(t)$ & $250(\mathrm{t})$ & $\begin{array}{l}4 \text { (laboratory } \\
\text { process) }\end{array}$ & 41.1 & 49 & $\begin{array}{l}\text { Employment } \\
\text { figures } \\
\text { unavailable }\end{array}$ & $\begin{array}{l}\text { Employment } \\
\text { figures } \\
\text { unavailable }\end{array}$ & 307 million \\
\hline $\begin{array}{c}\text { Portland } \\
\text { cement }\end{array}$ & $\begin{array}{l}91,300 \\
\text { (t) }\end{array}$ & $92,600(\mathrm{t})$ & 116 (plants) & 76 & 76 & 18,100 & 18,100 & 8.3 billion \\
\hline Salt & $\begin{array}{l}40,300 \\
\text { (t) }\end{array}$ & $41,200(\mathrm{t})$ & $69(\mathrm{~m}$, solar $)$ & 120.02 & 122 & 4,100 & 4,100 & 1 billion \\
\hline Talc & $775(t)$ & $817(\mathrm{t})$ & $9(\mathrm{~m})$ & 96 & 114 & 510 & 500 & 19 million \\
\hline *Zeolite & $\begin{array}{l}36.4(\mathrm{t}- \\
2001)\end{array}$ & $46(t-2003)$ & $9(\mathrm{p}, \mathrm{m})$ & $\begin{array}{r}60-320 \\
(2001)\end{array}$ & $\begin{array}{c}\text { Not } \\
\text { available }\end{array}$ & $\begin{array}{l}\text { Employment } \\
\text { figures } \\
\text { unavailable }\end{array}$ & $\begin{array}{c}\text { Employment } \\
\text { figures } \\
\text { unavailable }\end{array}$ & $\begin{array}{c}\text { Total value } \\
\text { unavailable for } \\
2003\end{array}$ \\
\hline
\end{tabular}

Data based on U.S. Geological Survey Mineral Commodity Summaries, 2004, http://minerals.er.usgs.gov/minerals/pubs/mcs/2004.

*Data provided by Robert L. Virta, U.S. Geological Survey, Reston, VA, March 2004. 


\begin{tabular}{|c|c|c|c|}
\hline \multirow[t]{2}{*}{$\begin{array}{l}\text { Industrial } \\
\text { mineral }\end{array}$} & \multicolumn{2}{|c|}{$\begin{array}{l}\text { World production excluding U.S. in thousand } \\
\text { metric tons (t, thousand) }\end{array}$} & \multirow[t]{2}{*}{ Principal countries of production outside U.S. } \\
\hline & 2002 & 2003 & \\
\hline Bentonite & $6,030(\mathrm{t})$ & $6,130(\mathrm{t})$ & $\begin{array}{l}\text { Brazil, Czech Republic, Germany, Greece, Italy, } \\
\text { Mexico, Turkey }\end{array}$ \\
\hline Borates & $3,530(\mathrm{t})$ & $3,290(\mathrm{t})$ & $\begin{array}{l}\text { Argentina, Bolivia, Chile, People's Republic of China, Russia, } \\
\text { Turkey, Iran, Peru }\end{array}$ \\
\hline $\begin{array}{c}\text { Crushed } \\
\text { stone, sand, } \\
\text { and gravel }\end{array}$ & 15 billion metric tons & Large & Most developed countries \\
\hline $\begin{array}{l}\text { Dimension } \\
\text { stone }\end{array}$ & Sufficient & Sufficient & Italy, Canada, India, Spain, Brazil \\
\hline Gypsum & $85,300(\mathrm{t})$ & $86,000(t)$ & $\begin{array}{l}\text { Iran, Canada, People's Republic of China, Thailand, Spain, } \\
\text { Japan, Australia }\end{array}$ \\
\hline $\begin{array}{l}\text { Refined } \\
\text { silicon }\end{array}$ & $3,459(\mathrm{t})$ & $3,750(\mathrm{t})$ & $\begin{array}{l}\text { People's Republic of China, Russia, Ukraine, Brazil, France, } \\
\text { Norway }\end{array}$ \\
\hline $\begin{array}{c}\text { Portland } \\
\text { cement }\end{array}$ & $1,708,700(\mathrm{t})$ & $1,767,400(\mathrm{t})$ & $\begin{array}{l}\text { People's Republic of China, India, Japan, Republic of Korea, } \\
\text { Brazil, Indonesia, Turkey }\end{array}$ \\
\hline Salt & $169,700(t)$ & $168,800(\mathrm{t})$ & $\begin{array}{l}\text { People's Republic of China, Canada, India, Germany, Australia, } \\
\text { Poland, United Kingdom }\end{array}$ \\
\hline Talc & $8,095(\mathrm{t})$ & $8,043(\mathrm{t})$ & $\begin{array}{l}\text { People's Republic of China, Republic of Korea, Japan, India, } \\
\text { Brazil }\end{array}$ \\
\hline Zeolite & $\begin{array}{l}\text { approximately } 2,736,500 \\
\text { metric tons }(2001)\end{array}$ & $\begin{array}{l}\text { Data not } \\
\text { available }\end{array}$ & $\begin{array}{l}\text { People's Republic of China, Japan, Cuba, Hungary, Slovakia, } \\
\text { Georgia, New Zealand, Greece }\end{array}$ \\
\hline
\end{tabular}

Data based on U.S. Geological Survey Mineral Commodity Summaries, January 2004, http://minerals.er.usgs.gov/minerals/pubs/mcs/2004. 